\title{
Evaluating the effect of alternative carbon allocation schemes in a land surface model (CLM4.5) on carbon fluxes, pools, and turnover in temperate forests
}

\author{
Francesc Montané ${ }^{1}$, Andrew M. Fox ${ }^{1}$, Avelino F. Arellano ${ }^{2}$, Natasha MacBean ${ }^{1}$, M. Ross Alexander ${ }^{1,3}$, Alex Dye ${ }^{4}$, \\ Daniel A. Bishop ${ }^{5}$, Valerie Trouet ${ }^{3}$, Flurin Babst ${ }^{3,6,7}$, Amy E. Hessl ${ }^{4}$, Neil Pederson ${ }^{8}$, Peter D. Blanken ${ }^{9}$, Gil Bohrer ${ }^{10}$, \\ Christopher M. Gough ${ }^{11}$, Marcy E. Litvak ${ }^{12}$, Kimberly A. Novick ${ }^{13}$, Richard P. Phillips ${ }^{14}$, Jeffrey D. Wood ${ }^{15}$, and \\ David J. P. Moore ${ }^{1}$ \\ ${ }^{1}$ School of Natural Resources and the Environment, University of Arizona, Tucson, Arizona, 85721, USA \\ ${ }^{2}$ Department of Hydrology and Atmospheric Sciences, University of Arizona, Tucson, Arizona, 85721, USA \\ ${ }^{3}$ Laboratory of Tree-Ring Res., University of Arizona, Tucson, Arizona, 85721, USA \\ ${ }^{4}$ Department of Geology and Geography, West Virginia University, Morgantown, West Virginia, 26506, USA \\ ${ }^{5}$ Division of Biology and Paleo Environment, Lamont-Doherty Earth Observatory, Columbia University, Palisades, \\ New York, 10964, USA \\ ${ }^{6}$ Dendro Sciences Unit, Swiss Federal Research Institute WSL, Zürcherstrasse 111, 8903 Birmensdorf, Switzerland \\ ${ }^{7}$ W. Szafer Institute of Botany, Polish Academy of Sciences, ul. Lubicz 46, 31-512 Krakow, Poland \\ ${ }^{8}$ Harvard Forest, Harvard University, Petersham, Massachusetts, 01366, USA \\ ${ }^{9}$ Department of Geography, University of Colorado, Boulder, Colorado, 80309, USA \\ ${ }^{10}$ Department of Civil, Environmental, and Geodetic Engineering, The Ohio State University, Columbus, Ohio, 43210, USA \\ ${ }^{11}$ Department of Biology, Virginia Commonwealth University, Richmond, Virginia, 23284, USA \\ ${ }^{12}$ Department of Biology, University of New Mexico, Albuquerque, New Mexico, 87131, USA \\ ${ }^{13}$ School of Public and Environmental Affairs, Indiana University, Bloomington, Indiana, 47405, USA \\ ${ }^{14}$ Department of Biology, Indiana University, Bloomington, Indiana, 47405, USA \\ ${ }^{15}$ School of Natural Resources, University of Missouri, Columbia, Missouri, 65211, USA
}

Correspondence to: Francesc Montané (francesc.montane@gmail.com)

Received: 15 March 2017 - Discussion started: 21 March 2017

Revised: 18 July 2017 - Accepted: 30 July 2017 - Published: 22 September 2017

\begin{abstract}
How carbon (C) is allocated to different plant tissues (leaves, stem, and roots) determines how long $\mathrm{C}$ remains in plant biomass and thus remains a central challenge for understanding the global $\mathrm{C}$ cycle. We used a diverse set of observations (AmeriFlux eddy covariance tower observations, biomass estimates from tree-ring data, and leaf area index (LAI) measurements) to compare C fluxes, pools, and LAI data with those predicted by a land surface model (LSM), the Community Land Model (CLM4.5). We ran CLM4.5 for nine temperate (including evergreen and deciduous) forests in North America between 1980 and 2013 using four different $\mathrm{C}$ allocation schemes:
\end{abstract}

i. dynamic C allocation scheme (named "D-CLM4.5") with one dynamic allometric parameter, which allocates $\mathrm{C}$ to the stem and leaves to vary in time as a function of annual net primary production (NPP);

ii. an alternative dynamic $\mathrm{C}$ allocation scheme (named " $\mathrm{D}$ Litton"), where, similar to (i), C allocation is a dynamic function of annual NPP, but unlike (i) includes two dynamic allometric parameters involving allocation to leaves, stem, and coarse roots;

iii.-iv. a fixed $\mathrm{C}$ allocation scheme with two variants, one representative of observations in evergreen (named " $\mathrm{F}$ - 
Evergreen") and the other of observations in deciduous forests (named "F-Deciduous").

D-CLM4.5 generally overestimated gross primary production (GPP) and ecosystem respiration, and underestimated net ecosystem exchange (NEE). In D-CLM4.5, initial aboveground biomass in 1980 was largely overestimated (between 10527 and $12897 \mathrm{~g} \mathrm{C} \mathrm{m}^{-2}$ ) for deciduous forests, whereas aboveground biomass accumulation through time (between 1980 and 2011) was highly underestimated (between 1222 and $7557 \mathrm{~g} \mathrm{C} \mathrm{m}^{-2}$ ) for both evergreen and deciduous sites due to a lower stem turnover rate in the sites than the one used in the model. D-CLM4.5 overestimated LAI in both evergreen and deciduous sites because the leaf C-LAI relationship in the model did not match the observed leaf $\mathrm{C}-$ LAI relationship at our sites. Although the four $\mathrm{C}$ allocation schemes gave similar results for aggregated $\mathrm{C}$ fluxes, they translated to important differences in long-term aboveground biomass accumulation and aboveground NPP. For deciduous forests, D-Litton gave more realistic $\mathrm{C}_{\text {stem }} / \mathrm{C}_{\text {leaf }}$ ratios and strongly reduced the overestimation of initial aboveground biomass and aboveground NPP for deciduous forests by D-CLM4.5. We identified key structural and parameterization deficits that need refinement to improve the accuracy of LSMs in the near future. These include changing how $\mathrm{C}$ is allocated in fixed and dynamic schemes based on data from current forest syntheses and different parameterization of allocation schemes for different forest types.Our results highlight the utility of using measurements of aboveground biomass to evaluate and constrain the $\mathrm{C}$ allocation scheme in LSMs, and suggest that stem turnover is overestimated by CLM4.5 for these AmeriFlux sites. Understanding the controls of turnover will be critical to improving long-term $\mathrm{C}$ processes in LSMs.

\section{Introduction}

Over the last half century, on average a little more than a quarter of global $\mathrm{CO}_{2}$ emissions were absorbed by terrestrial carbon (C) sinks (Le Quéré et al., 2015), with forests accounting for most (Malhi et al., 2002; Bonan, 2008; Pan et al., 2011; Baldocchi et al., 2016). The interannual variability in the land $\mathrm{C}$ sink is high, representing up to $80 \%$ of annual $\mathrm{CO}_{2}$ emissions (Le Quéré et al., 2009). The mechanism by which forests accumulate $\mathrm{C}$ is through photosynthetic uptake and allocation of the $\mathrm{C}$ to biomass in different plant pools (leaf, stem, and root). The $\mathrm{C}$ stored in biomass stocks are determined mainly by the $\mathrm{C}$ fluxes and the $\mathrm{C}$ allocation amongst plant pools.

The amount of carbon stored in biomass is dependent on how photosynthetically fixed carbon is allocated between $\mathrm{C}$ pools and how long these pools persist (Bloom et al., 2016; Koven et al., 2015; De Kauwe et al., 2014). How long-lived different plant pools are (leaf, stem, and root) influences whether ecosystems are projected to act as $\mathrm{C}$ sources or sinks (Delbart et al., 2010; Friend et al., 2014). Once C is taken up by the plant, the carbon is allocated either to short-lived leaf or fine-root tissues, or to longer-lived woody tissues. Here we use turnover time of $\mathrm{C}$ in a plant pool as the total carbon pool divided by the total flux into or out of the pool (Sierra et al., 2017). Plants that allocate a greater proportion of $\mathrm{C}$ to tissues with long turnover times (e.g., stem) have a higher standing biomass than the plants that allocate a greater proportion of $\mathrm{C}$ to tissues with short turnover times (e.g., leaf). Ecological theory suggests that variation in $\mathrm{C}$ allocation to different plant pools is governed by functional trade-offs (Tilman, 1988), with plants investing in either aboveground or belowground tissues depending on which strategy would maximize growth and reproduction. If the functional trade-off hypothesis is relevant on forest or regional scales, land surface models (LSMs) for forests should represent it using dynamic $\mathrm{C}$ allocation schemes, which are responsive to above- (e.g., light) and belowground (e.g., water or nutrients) factors that limit growth.

Allocation of $\mathrm{C}$ between pools in terrestrial ecosystems is poorly represented in LSMs (Delbart et al., 2010; Malhi et al., 2011; Negron-Juarez et al., 2015). Some LSMs use fixed ratios for each plant functional type (PFT), while other models use allocation fractions that are altered by environmental conditions (Wolf et al., 2011; De Kauwe et al 2014). Though many LSMs use the same fractional allocation for both evergreen and deciduous forests, global syntheses show differences in inferred $\mathrm{C}$ allocation patterns, for example, the percentage of NPP allocated to leaves that is greater in deciduous than in evergreen forests (Luyssaert et al., 2007). In part this is because it is difficult to measure allocation to different pools on ecosystem or landscape scales, and instead we infer what partitioning was required to result in different biomass pools. While eddy covariance observations can be used to parameterize and benchmark LSMs either at single sites or, using geospatial scaling methods, across regions or the globe (Baldocchi et al., 2001; Friend et al., 2007; Randerson et al., 2009; Zaehle and Friend, 2010; Mahecha et al., 2010; Bonan et al., 2011), these data inform fluxes in and out but do not provide information on allocation between pools (Richardson et al., 2010).

Studies focusing simultaneously on $\mathrm{C}$ pools, fluxes and allocation are relatively rare (Wolf et al., 2011; Xia et al., 2015; Bloom et al., 2016; Thum et al., 2017), in part because collecting biometric data in addition to flux data is very labor-intensive. Some forest inventory data include estimates of the average biomass within the leaf, wood and root pool, and these can be used to parameterize and benchmark models (Caspersen et al., 2000; Brown, 2002; Houghton, 2005; Keith et al., 2009). The AmeriFlux network provides a rare opportunity to investigate forest allocation processes because gross primary productivity and respiration fluxes are quantified continuously. However, measurements of pool sizes in 
leaves, stems, etc., are less available at these sites and so have been less frequently explored.

In this study, we evaluate mechanisms by which $\mathrm{C}$ is stored over multiple decades in plant biomass using corresponding eddy covariance flux towers and biometric measurements of $\mathrm{C}$ storage in different pools. We collated biometric data (aboveground biomass and leaf area index), where available, for AmeriFlux sites and supplemented these data with novel aboveground biomass estimates from tree-ring data for AmeriFlux sites (Alexander et al., 2017). We evaluate two dynamic C allocation schemes (Oleson et al., 2013; Litton et al., 2007) and two fixed C allocation schemes (Luyssaert et al., 2007) within the Community Land Model (CLM4.5) against $\mathrm{C}$ fluxes, stocks, and leaf area index (LAI) data at nine temperate North American forest ecosystems.

\section{Methods}

We implemented the CLM4.5 model - a well-established and commonly used LSM - at nine different forest sites (Sect. 2.1) and compiled observation of $\mathrm{C}$ fluxes, $\mathrm{C}$ pools, $\mathrm{LAI}$, and the $\mathrm{C}_{\text {stem }} / \mathrm{C}_{\text {leaf }}$ ratio (Sect. 2.2) to evaluate alternative $\mathrm{C}$ allocation structures and parameterizations (Sects. 2.3 and 2.4). We re-parameterized the specific leaf area (SLA) based on available observations (Sect. 2.5) before implementing four CLM4.5 model experiments designed to examine the impact of the different $\mathrm{C}$ allocation structures and parameterizations (Sect. 2.6). Finally, to investigate the potential effects of site variation in woody turnover, we estimated plausible site-specific turnover rates (Sect. 2.7).

\subsection{Study sites}

Nine temperate forests widely distributed throughout the USA were selected for this study, including four evergreen (Niwot Ridge, Valles Caldera mixed conifer, Howland Forest, and Duke Forest loblolly pine) and five deciduous forests (University of Michigan Biological Station, Missouri Ozark, Harvard Forest, Morgan Monroe State Forest, and Duke Forest hardwoods; Table 1). All the selected forests are AmeriFlux sites (http://ameriflux.lbl.gov/), a network of eddy covariance sites measuring ecosystem $\mathrm{C}$, water, and the energy fluxes in North and South America. AmeriFlux datasets provide central connections between terrestrial ecosystem processes and climate responses from site to continental scale, and are part of FLUXNET, a global network of eddy covariance measurements being made on all continents.

\subsection{Observations}

We compiled different data streams from diverse sources for the sites (Table 1) for benchmarking $\mathrm{C}$ fluxes, $\mathrm{C}$ pools, and LAI in the model experiments. Some of the data were only available for a subset of sites and years (Table 1).
To quantify carbon flux into and out of the different forests, eddy covariance measurements were collated from the AmeriFlux L2 gap-filled data product (Boden et al., 2013; http://ameriflux.lbl.gov/data/download-data/) for all sites, except for Niwot Ridge where only the AmeriFlux L2 with-gaps data product was available; there we used the REddyProc package (Reichstein et al., 2005) to gap-fill and partition the data (Table 1). Half-hourly eddy covariance flux data were aggregated to annual values at all sites. While partitioning and uncertainty analyses were available from the FLUXNET2015 dataset (http://fluxnet.fluxdata.org/data/ fluxnet2015-dataset/) only for some sites, we opted to use only AmeriFlux L2 data and process all sites using the same protocol.

To quantify the how much carbon was stored in aboveground woody biomass and leaf biomass in these forests, we collated already existing biomass and LAI estimates from the AmeriFlux network; these were available for only some sites and years (Table 1). LAI measured in situ was available from AmeriFlux data for some sites (Table 1), and we used the annual maximum LAI for all the available measurements in each year. We used the leaf C-LAI ratio from the AmeriFlux sites with simultaneous measurements of LAI and leaf $\mathrm{C}$ during the same year (Table 1). The $\mathrm{C}_{\text {stem }} / \mathrm{C}_{\text {leaf }}$ ratio, which was derived from AmeriFlux data with $\mathrm{C}_{\text {stem }}$ and $\mathrm{C}_{\text {leaf }}$ estimates for the same year, was only available for a subset of sites and years (Table 1).

To quantify aboveground biomass at all of the sites, we surveyed each forest and calculated aboveground biomass between 1980 and 2011 (Table 1) using a dendrochronological sampling technique (Dye et al., 2016; Alexander et al., 2017). This provided a reconstruction of year-to-year variability in diameter at breast height (dbh) of trees and biomass inferred from allometric regressions. Briefly, the dbh of trees within a $20 \mathrm{~m}$ diameter plot was measured; all trees above $10 \mathrm{~cm}$ in diameter were sampled within $13 \mathrm{~m}$, and trees larger than $20 \mathrm{~cm}$ dbh were sampled in the remainder of the plot. In Valles Caldera, rather than subsampling within a $20 \mathrm{~m}$ plot, all trees were sampled from two central locations until 50 samples were collected from each location following Babst et al. (2014). At the Niwot site, a point-centered quarter method (Stearns, 1949; Cottam et al., 1953) was used to estimate stand density and to select individuals for sampling. Species, dbh, and canopy position were recorded for each tree within the plots. Increment cores were dried, mounted, and sanded using standard dendrochronological procedures (Stokes and Smiley, 1968). Increments were first visually cross-dated (Douglass, 1941) and then measured under a binocular microscope and statistically cross-dated using COFECHA software (Holmes, 1983; Grissino-Mayer, 2001). Ring widths were scaled to dbh, and allometric equations (Jenkins et al., 2004; Chojnacky et al., 2014) were applied to estimate biomass through time. When available site- or region-specific allometric equations were applied, and generalized species-level allometric equations were used 


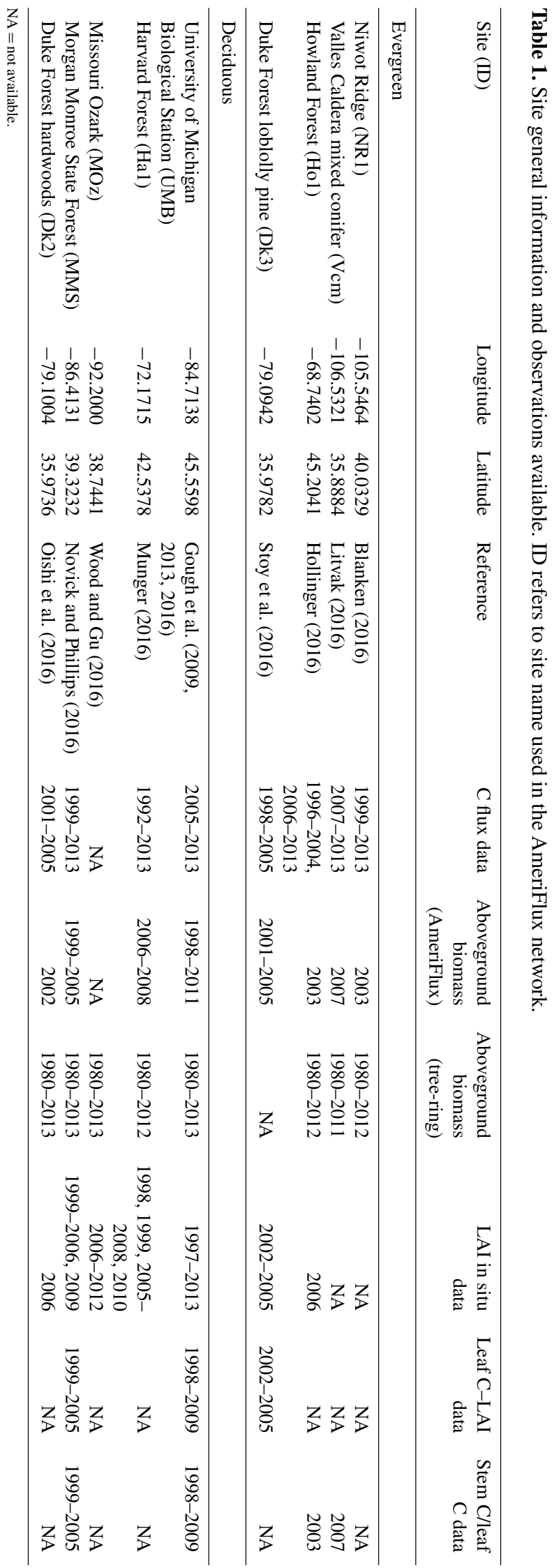

where these were not available. Trees that were sampled but lacked sufficient tree-ring data were gap-filled with a generalized additive mixed model to account for their biomass on the landscape (Alexander et al., 2017). At Harvard and Howland, tree-ring reconstructed biomass was compared to biomass estimated from permanent plots established in 1969 and 1989, respectively; tree-ring biomass increment estimates fell within the $95 \%$ confidence intervals of biomass estimated from the permanent plots (Dye et al., 2016). Both permanent plots and tree-ring reconstructed biomass are dependent on allometric equations, which contributes to uncertainty in these values.

\subsection{C allocation scheme in CLM}

The Community Land Model (CLM version 4.5) was used to simulate $\mathrm{C}$ fluxes, $\mathrm{C}$ pools and LAI at single points (Oleson et al., 2013). CLM4.5 is a component of the Community Earth System Model (CESM1.2) of the National Center for Atmospheric Research (Oleson et al., 2013).

CLM4.5 assumes that vegetated surfaces are comprised of different plant functional types. Our sites had two different PFTs: "needleleaf evergreen tree - temperate" for evergreen forests and "broadleaf deciduous tree - temperate" for deciduous forests.

CLM4.5 includes the following plant tissue types: leaf, stem (live and dead stem), coarse root (live and dead coarse root), and fine root (Oleson et al., 2013). The model calculates carbon allocated to new growth based on three allometric parameters that relate allocation between tissue types (Oleson et al., 2013): $a_{1}$ (ratio of new fine root to new leaf carbon allocation), $a_{2}$ (ratio of new coarse root to new stem carbon allocation), and $a_{3}$ (ratio of new stem to new leaf carbon allocation). CLM4.5 has a dynamic allocation scheme (named "D-CLM4.5"), which is described in Oleson et al. (2013), that includes one dynamic allometric parameter (as a function of annual NPP) and two constant allometric parameters. In D-CLM4.5 (see Table 2), for the PFTs in our sites $a_{1}$ and $a_{2}$ are constant $\left(a_{1}=1, a_{2}=0.3\right)$, whereas $a_{3}$ is a dynamic parameter defined by the following equation:

$a_{3}=\frac{2.7}{1+e^{-0.004 \cdot(\mathrm{NPPann}-300)}}-0.4$,

where NPPann is the annual sum of NPP of the previous year. The above equation for $a_{3}$ increases stem allocation relative to leaf when annual NPP increases. For instance, when annual NPP is $0 \mathrm{~g} \mathrm{C} \mathrm{m}^{-2} \mathrm{yr}^{-1}, a_{3}$ is 0.20 (e.g., 0.2 units of $\mathrm{C}$ allocated to stem for 1 unit of $\mathrm{C}$ allocated to leaf), whereas when NPP is close to $1000 \mathrm{~g} \mathrm{C} \mathrm{m}^{-2} \mathrm{yr}^{-1}$ or greater, $a_{3}$ is constrained to not exceed 2.2 (e.g., 2.2 units of $\mathrm{C}$ allocated to stem for 1 unit of $\mathrm{C}$ allocated to leaf). Therefore, when annual NPP is relatively close to $1000 \mathrm{~g} \mathrm{C} \mathrm{m}^{-2} \mathrm{yr}^{-1}$ or greater, the $\mathrm{C}$ allocation scheme becomes fixed with the following values for the parameters: $a_{1}=1, a_{2}=0.3$, and $a_{3}=2.2$. To account for the range of NPP found in temperate forests, 
Table 2. Allometric parameter values for evergreen and deciduous temperate forests in the $\mathrm{C}$ allocation scheme in CLM described in Oleson et al. (2013; D-CLM4.5); the alternative dynamic C allocation scheme (D-Litton) based on Litton et al. (2007); and the 2 fixed C allocation schemes (F-Evergreen, and F-Deciduous) based on Luyssaert et al. (2007). Allometric parameters represented with numbers indicate constant parameters, whereas equations indicate dynamic parameters. In the equations, NPPann is the annual sum of net primary productivity (NPP) of the previous year.

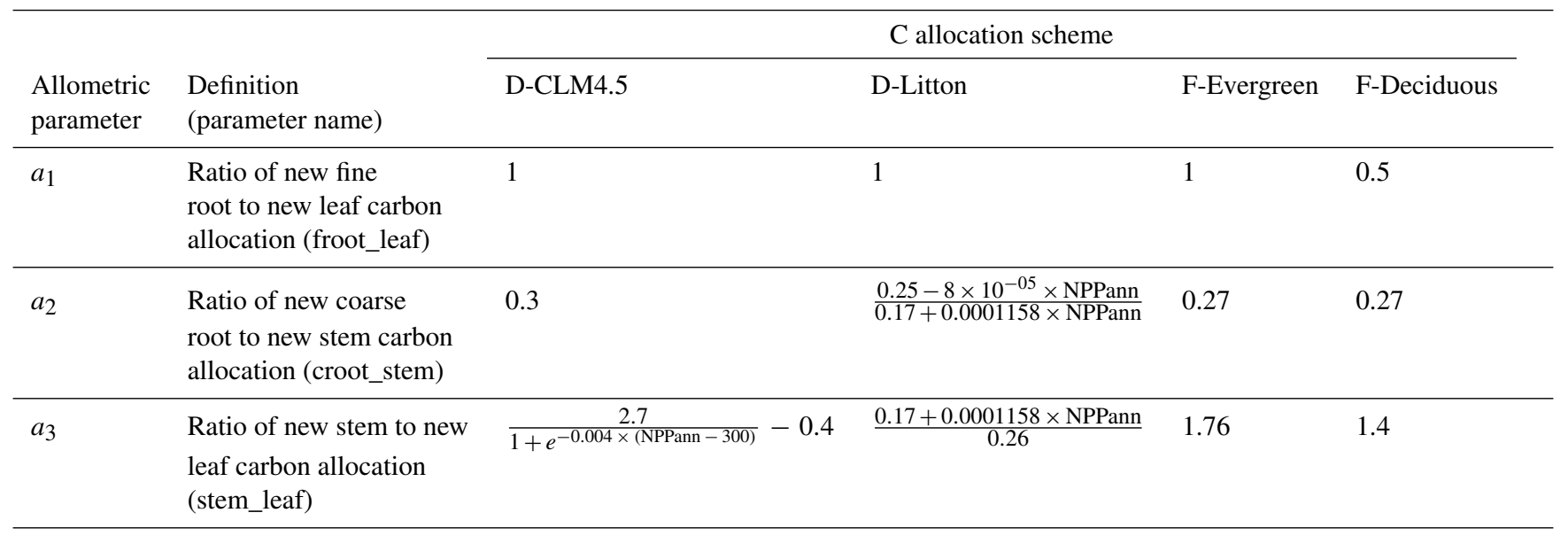

we calculated the allometric parameters $a_{1}, a_{2}$, and $a_{3}$ for a broad range of NPP, and then converted the allometric parameters to allocation coefficients for each plant tissue using the $\mathrm{C}$ allometry in the model (Oleson et al., 2013). We illustrate in one figure the effect of annual NPP on C allocation to each plant tissue in D-CLM4.5 (Fig. S1 in the Supplement).

\subsection{Alternative $\mathrm{C}$ allocation structures and parameterizations}

In addition to the dynamic $\mathrm{C}$ allocation structure in CLM4.5 (Oleson et al., 2013), we implemented an alternative dynamic (Litton et al., 2007) and two fixed (Luyssaert et al., 2007) C allocation parameterizations with the same structure.

The alternative dynamic $\mathrm{C}$ allocation structure (named " $\mathrm{D}$ Litton") was based on carbon partitioning data along an annual GPP gradient from Litton et al. (2007), and it considered two dynamic allometric parameters. We adapted the original equations reported in Litton et al. (2007), converted the GPP gradient to a NPP gradient with the general assumption that $\mathrm{NPP}=0.5 \times$ GPP (Waring et al., 1998; Gifford, 2003) and used the modified equations to calculate the allometric parameters used in CLM4.5. The partitioning between coarse root and fine root was not provided, and we used the default value for parameter $a_{1}\left(a_{1}=1\right)$. The other allometric parameters $\left(a_{2}\right.$ and $\left.a_{3}\right)$ were dynamic, and the equations used for them are shown in Table 2.

The two alternative fixed $\mathrm{C}$ schemes have the same structure but different allocation parameterizations and were based on observed values reported by Luyssaert et al. (2007), which were converted accordingly to the allometric parameters used in CLM. One of the C allocation parameter sets was representative of temperate evergreen forests (named
"F-Evergreen") and the other of temperate broadleaf deciduous forests (named "F-Deciduous"). Similarly to Litton et al. (2007), Luyssaert et al. (2007) only provided total root allocation without considering coarse and fine root, but the default value for parameter $a_{1}\left(a_{1}=1\right)$ was not possible in some cases. We thus initially used a range of possible values for parameter $a_{1}\left(a_{1}=1, a_{1}=0.75\right.$ and $\left.a_{1}=0.5\right)$ for model runs. When these values were based on those in Luyssaert et al. (2007) where allocation to leaf was lower than total root allocation, we used the default value for parameter $a_{1}\left(a_{1}=1\right.$ for F-Evergreen); but when based on the values in Luyssaert et al. (2007) where allocation to leaf was higher than total root allocation, the $a_{1}$ parameter had to be lower than 1 . This was the case for the F-Deciduous $\mathrm{C}$ allocation parameterization, and because $a_{1}=0.75$ gave unrealistic aboveground : belowground ratios, we used $a_{1}=0.5$. The allometric parameters used for the F-Evergreen and FDeciduous $\mathrm{C}$ allocation parameterizations are shown in Table 2.

\subsection{LAI in CLM}

CLM4.5 uses a prognostic canopy model, with feedbacks between GPP and LAI acting through allocation to leaf $\mathrm{C}$ and SLA and with SLA being a critical fixed parameter in this feedback pathway (Thornton and Zimmermann, 2007). The model assumes a linear relationship between SLA and the canopy depth $(x)$ :

$\operatorname{SLA}(x)=\mathrm{SLA}_{0}+m x$,

where $\mathrm{SLA}_{0}\left(\mathrm{~m}^{2}\right.$ one-sided leaf area $\left.\mathrm{g} \mathrm{C}^{-1}\right)$ is a fixed value of SLA at the top of the canopy, $m$ is a linear slope coefficient, and $x$ is the canopy depth expressed as overlying leaf 
area index $\left(\mathrm{m}^{2}\right.$ overlying one-sided leaf area $\mathrm{m}^{-2}$ ground area). LAI is calculated for a given leaf $\mathrm{C}\left(\mathrm{C}_{\mathrm{L}}\right)$ using the following equation:

$\mathrm{LAI}=\frac{\mathrm{SLA}_{0}\left[\exp \left(m C_{\mathrm{L}}\right)-1\right]}{m}$,

where $m\left(\mathrm{~m}^{2}\right.$ ground area $\left.\mathrm{g} \mathrm{C}^{-1}\right)$ and $\mathrm{SLA}_{0}\left(\mathrm{~m}^{2}\right.$ one-sided leaf area $\mathrm{g} \mathrm{C}^{-1}$ ) are different parameters for each PFT. In the case of temperate evergreen forests the default values for $m$ and SLA $\mathrm{S}_{0}$ in CLM4.5 are 0.00125 and 0.010 , whereas for temperate broadleaf deciduous forests $m=0.004$ and $\mathrm{SLA}_{0}=0.030$ (Oleson et al., 2013).

We compared leaf C-LAI data from available sites with the leaf C-LAI relationship in the model. For deciduous sites, we optimized the model parameters based on observed leaf C-LAI. To avoid using unrealistic values for the parameters $m$ and $\mathrm{SLA}_{0}$, we took a range of possible values for both parameters from Thornton and Zimmermann (2007), and used an optimization approach based on least squares that combined the range of parameter values and Eq. (3) to find the best combination of values for the two parameters given the leaf C-LAI observations at our sites. After optimizing the parameters $m$ and $\mathrm{SLA}_{0}$, we used $m=0.0010$ and $\mathrm{SLA}_{0}=0.024$ for deciduous forests. For evergreen sites, we could not optimize the parameters $m$ and $\mathrm{SLA}_{0}$ due to the limited number of leaf C-LAI observations available. All model experiments were carried out after SLA optimization.

\subsection{Testing allocation schemes in CLM4.5}

All CLM4.5 modeling experiments were run for nine sites, including four evergreen and five deciduous forests (see Table 1). For evergreen sites, we used the default leaf C-LAI relationship in CLM4.5, whereas for deciduous forests we used the optimized leaf C-LAI relationship (Sect. 2.5).

Each experiment represents a different allocation scheme. For experiment 1 we used the original dynamic $\mathrm{C}$ allocation structure in CLM4.5 (D-CLM4.5; see Sect. 2.3). For experiment 2 , we used the alternative dynamic $\mathrm{C}$ allocation structure based on Litton et al. (2007; D-Litton, see Sect. 2.4). For experiments 3 and 4 , we used a fixed $C$ allocation structure representative of evergreen (F-Evergreen) and deciduous (FDeciduous) forests, respectively (Luyssaert et al., 2007 - see Sect. 2.4).

The standard climate forcing provided with the model is the 1901-2013 CRUNCEP dataset. While meteorological data are available at the AmeriFlux sites, these data extend only as long as the eddy covariance observations, which are less than a decade in several cases. To explore the effects of allocation on slowly changing $\mathrm{C}$ pools like woody biomass, we extended model runs to 30 years, which requires using CRUNCEP or some other reanalysis climate. The CRUNCEP dataset has been used to force CLM for studies of vegetation growth, evapotranspiration, and gross primary production (Mao et al., 2012, 2013; Shi et al., 2013; Chen et al., 2016), as well as for the TRENDY (trends in net landatmosphere carbon exchange over the period 1980-2010) project (Piao et al., 2012).

In all the experiments, we spun up the model for each site and C allocation scheme using 1901-1920 CRUNCEP climate and assuming preindustrial atmospheric $\mathrm{CO}_{2}$ concentration in order to bring all above- and belowground $\mathrm{C}$ pools to equilibrium. We used the initial conditions resulting from the spin-up to perform a 1901-2013 transient run (e.g., 1901-2013 CRUNCEP transient climate, transient atmospheric $\mathrm{CO}_{2}$ concentration). Observations were compared with model outputs for the period between 1980 and 2013.

\subsection{Sensitivity of biomass increment to stem turnover rate}

In CLM4.5 the stem turnover rate is dominated by how much woody $\mathrm{C}$ is lost each year through senescence (mortality and litter). Here we define turnover time as the total $\mathrm{C}$ pool divided by the rate of $\mathrm{C}$ input or output. We estimated a range of plausible, site-specific stem turnover rates using Eq. (4) below because, at individual research forest stands, rates of tree mortality may or may not reflect averages rates across larger areas. LSMs are typically run on scales that are coarser than those for individual forest sites and use aggregate estimates for turnover of different C pools. CLM4.5, like many models, is based on differential equations for the calculation of changing biomass with time, which can be expressed as follows:

$\mathrm{d} B_{i} / \mathrm{d} t=a_{i} \mathrm{NPP}-u_{i} B_{i}$,

where $i$ is a given plant pool, $B_{i}$ is the biomass of that pool, $\mathrm{d} B_{i} / \mathrm{d} t$ is the biomass increment with time for each plant pool, $a_{i}$ is the allocation coefficient to that plant pool (allocation coefficients for all pools combined sum to 1 ), and $u_{i}$ is the turnover rate for each component. We considered leaf, stem, coarse root, and fine root as plant pools. To optimize the stem turnover rate we used Eq. (4) as a simplified offline model to modify the default stem turnover rate (2\%) to within a range of 0 to $2 \%$ (van Mantgem et al., 2009; Brown and Schroeder, 1999); for the rest of plant pools we used the default turnover rate in the model. In the simplified offline model, the annual NPP input was derived from the model for a given site using the default stem turnover ( $2 \%)$, and the initial biomass for each plant pool was derived from the model with a particular carbon allocation scheme and parameterization. We compared the differences in aboveground biomass (leaf and stem) increment over time based on different turnover rates with the aboveground biomass increments estimated from tree-ring data for our sites between 1980 and 2011. 


\section{Results}

\subsection{Carbon fluxes, and pools in D-CLM4.5}

When compared to observations from the AmeriFlux sites, D-CLM4.5 usually underestimated net ecosystem exchange (NEE; Fig. 1a), and overestimated GPP (Fig. 1b) and ecosystem respiration (Fig. 1c)

Initial aboveground biomass in 1980 showed contrasting patterns in D-CLM4.5 for evergreen and deciduous forests. At evergreen sites, aboveground biomass in 1980 was underestimated at sites with mean annual NPP $<500 \mathrm{~g} \mathrm{C} \mathrm{m}^{-2} \mathrm{yr}^{-1}$ (NR1 and $\mathrm{Vcm}$ ) and overestimated at the site with mean annual NPP $>500 \mathrm{~g} \mathrm{C} \mathrm{m}^{-2} \mathrm{yr}^{-1}$ (Ho1; Fig. 2a). Aboveground biomass in 1980 was largely overestimated at all deciduous sites (between 10527 and $12897 \mathrm{~g} \mathrm{C} \mathrm{m}^{-2}$; Fig. 2a). The accumulated aboveground biomass between 1980 and 2011 was largely underestimated in the model (difference between observations and model ranged between 1222 and $7557 \mathrm{~g} \mathrm{C} \mathrm{m}^{-2}$, depending on the site; Fig. 2b).

\subsection{LAI and $\mathrm{C}_{\text {stem }} / \mathrm{C}_{\text {leaf }}$ in D-CLM4.5}

D-CLM4.5 overestimated LAI relative to in situ LAI measurements (Fig. 3a). We compared the leaf C-LAI relationship with the observed leaf C-LAI and found important differences, especially for deciduous sites (Fig. 3b). We optimized the parameters $m$ and SLA 0 based on available observations for two deciduous sites (Fig. 3b). The modified LAI was closer to the LAI values measured in situ for all five deciduous sites (Fig. 3c).

The $\mathrm{C}_{\text {stem }} / \mathrm{C}_{\text {leaf }}$ ratio in the model was dramatically different from the observations (Fig. 4). The model overestimated the $\mathrm{C}_{\text {stem }} / \mathrm{C}_{\text {leaf }}$ ratio in 1 of the 2 years with available data for two evergreen sites, and all the 19 years with available data for two deciduous sites (Fig. 4; Table 1).

\subsection{Carbon fluxes, pools, and LAI in the alternative C allocation schemes}

D-CLM4.5 and the alternative $\mathrm{C}$ allocation schemes have important differences in $\mathrm{C}$ allocation to each plant tissue (see Fig. S1 in the Supplement). Some of the main differences between D-CLM4.5 and the alternative C allocation schemes include increased allocation to leaf and decreased allocation to stem, especially in D-Litton at sites with low mean annual NPP (see Fig. S1 in the Supplement).

The accumulated annual C fluxes (GPP, ecosystem respiration, and NEE) from 1980 to 2011 gave comparable results for the four $\mathrm{C}$ allocation schemes (Supplement Fig. 2). However, the $\mathrm{C}$ allocation schemes resulted in differences larger than $5000 \mathrm{~g} \mathrm{C} \mathrm{m}^{-2}$ in long-term aboveground biomass accumulation for all the sites (Fig. 5a and b). All C allocation schemes overestimated aboveground biomass in 1980 in all the sites, except in evergreen sites with mean annual $\mathrm{NPP}<500 \mathrm{~g} \mathrm{C} \mathrm{m}^{-2} \mathrm{yr}^{-1}$ (NR1 and $\mathrm{Vcm}$ ), where only the
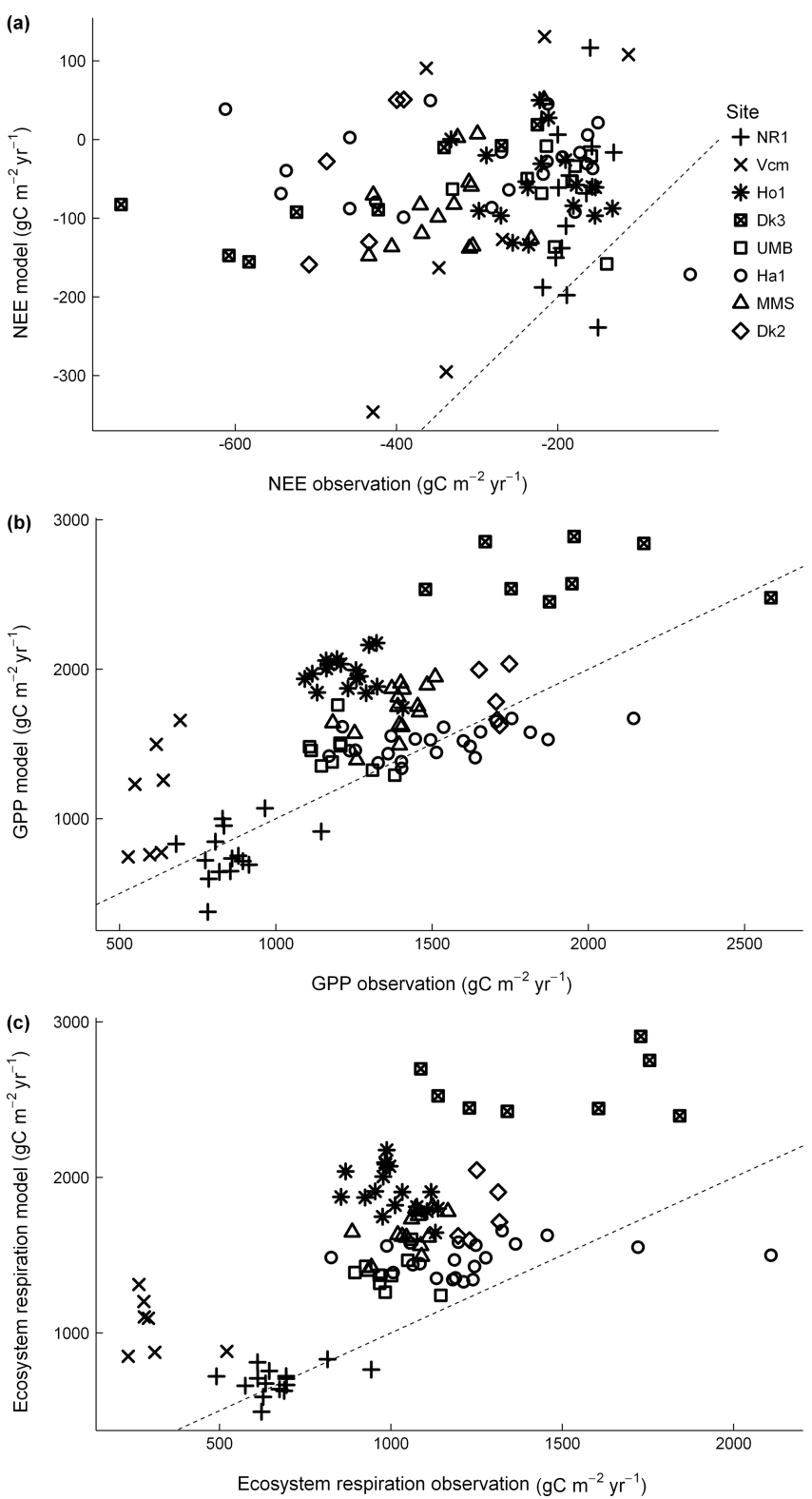

Figure 1. Comparisons between (a) NEE, (b) GPP, and (c) ecosystem respiration in observations and model (D-CLM4.5). All fluxes were aggregated to annual. Dashed line is $1: 1$ relationship between observations and model. Observations are from the AmeriFlux L2 data product.

F-Deciduous allocation overestimated aboveground biomass (Fig. 5a). The D-Litton allocation scheme underestimated aboveground biomass in 1980 at all evergreen sites and, despite overestimating it at all deciduous sites, this scheme gave the closest values to the observations (Fig. 5a). Similar results were found for mean aboveground biomass between 2002 and 2011 (Fig. 5b). Despite the differences in the total aboveground biomass, aboveground biomass annual increment in all the $\mathrm{C}$ allocation schemes was lower than that estimated from tree-ring data, and accumulated aboveground 

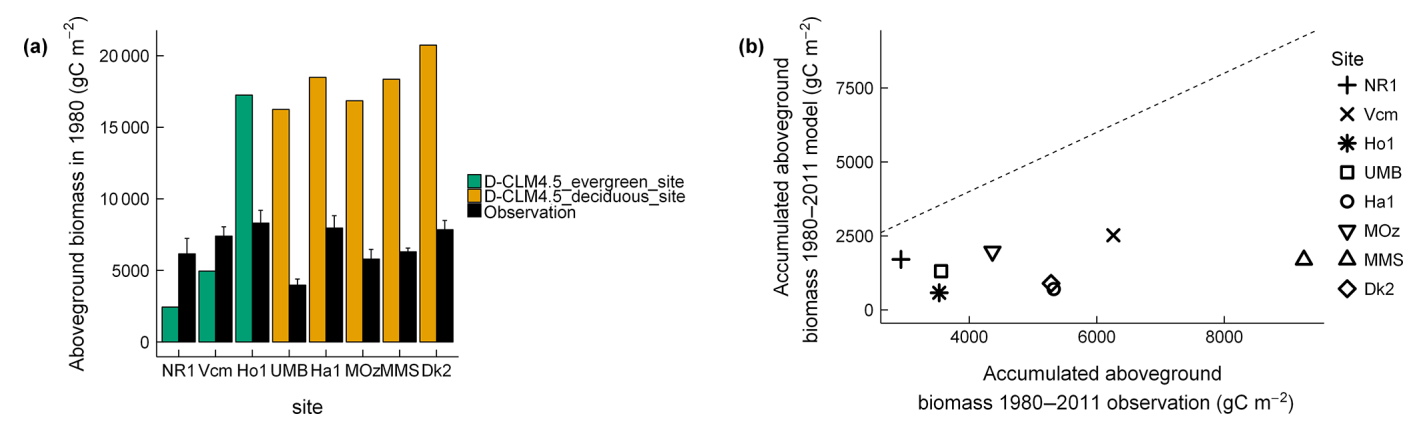

Figure 2. Comparisons (a) between observed and modeled (D-CLM4.5) aboveground biomass in 1980 and (b) between observed and modeled (D-CLM4.5) accumulated aboveground biomass between 1980-2011. Dashed line is 1: 1 relationship between observations and model. Observations (estimates of aboveground biomass from tree-ring data) for the Ho1 and Ha1 sites are from Dye et al. (2016), whereas for the rest of sites observations were obtained following the methodology described in Alexander et al. (2017).

biomass between 1980 and 2011 was therefore strongly underestimated assuming a mortality rate of $2 \% \mathrm{yr}^{-1}$ (Fig. $5 \mathrm{c}$ ).

The $\mathrm{C}$ allocation schemes showed differences of up to $10 \%$ in allocation to leaf, which produced large differences in LAI values (from $\sim 20$ to $\sim 4.5$ ) between allocation schemes (Fig. 6). In particular the F-Deciduous allocation gave high and unrealistic LAI values at evergreen sites (LAI $\sim 20$; Fig. 6), where the leaf C-LAI relationship was not optimized. At deciduous sites, using the optimized leaf CLAI relationship, the highest LAI values were $\sim 10$ (Fig. 6). The F-Deciduous allocation had an allocation to leaf that was $\sim 10 \%$ greater than the one in D-CLM; however, the FDeciduous allocation scheme with optimized LAI gave very similar LAI values to the D-CLM without optimizing the leaf C-LAI relationship (Fig. 6).

\subsection{Turnover rate and its effect on accumulated aboveground biomass through time}

The stem turnover rate that best matched the biomass accumulation rate estimated from the tree-ring reconstructions varied by site and was always lower than the default rate of $2 \% \mathrm{yr}^{-1}$ used in CLM4.5 (Fig. 7). As expected, changing the turnover rate had the largest influence at sites with the highest average NPP. Biomass accumulation in the D-Litton scheme was less sensitive to changes in turnover rate compared to the D-CLM scheme (compare Fig. 7b to a). The FDeciduous and F-Evergreen parameterization were similar in their sensitivity to changes in turnover rate (compare Fig. 7c to d).

\subsection{C allocation scheme and its effects on $C_{\text {stem }} / C_{\text {leaf }}$ ratio and initial aboveground biomass}

The partitioning between leaf and stem $\mathrm{C}$ at these sites was best predicted by the D-Litton scheme (Fig 8). For the range of annual NPP values at our sites (NPP $<1500 \mathrm{~g} \mathrm{C} \mathrm{m}^{-2} \mathrm{yr}^{-1}$ ), the $\mathrm{NPP}_{\text {stem }} / \mathrm{NPP}_{\text {leaf }}$ ratio was the lowest in the D-Litton scheme (Fig. 8b), which therefore resulted in the lowest
$\mathrm{C}_{\text {stem }} / \mathrm{C}_{\text {leaf }}$ ratios amongst the four $\mathrm{C}$ allocation schemes (Fig. 8a). The $\mathrm{C}_{\text {stem }} / \mathrm{C}_{\text {leaf }}$ ratios from the D-Litton scheme were also the closest to the observed values at all the sites with mean annual $\mathrm{NPP}>500 \mathrm{~g} \mathrm{C} \mathrm{m}^{-2} \mathrm{yr}^{-1}$ (Fig. 8a). The $\mathrm{NPP}_{\text {stem }} / \mathrm{NPP}_{\text {leaf }}$ ratio was overestimated in D-CLM4.5, and it caused overestimations in the $\mathrm{C}_{\text {stem }} / \mathrm{C}_{\text {leaf }}$ ratio, which ranged between 33 and 56 for deciduous sites (Figs. 4 and $8 a)$.

Initial aboveground biomass showed different patterns between evergreen and deciduous sites (Fig. 9a, b). Whereas for evergreen sites with annual $\mathrm{NPP}<500 \mathrm{~g} \mathrm{C} \mathrm{m}^{-2} \mathrm{yr}^{-1}$, there was some overlap between modeled and observed initial aboveground biomass, for deciduous sites modeled initial aboveground biomass was strongly overestimated (between 10527 and $12897 \mathrm{~g} \mathrm{C} \mathrm{m}^{-2}$ ) in D-CLM4.5 (Fig. 5a, Fig. 9b). The D-Litton scheme reduced the initial aboveground biomass relative to D-CLM4.5, but still with a positive bias (between 5040 and $6859 \mathrm{~g} \mathrm{C} \mathrm{m}^{-2}$; Figs. 5a and 9b).

\section{Discussion}

From the four $\mathrm{C}$ allocation schemes used, two were based on fixed coefficients (Luyssaert et al., 2007), whereas the other two were dynamic and based on optimization of resources (Oleson et al., 2013; Litton et al., 2007). Of these schemes, the dynamic scheme based on D-Litton performed better than the other three. Though this scheme is imperfect, we note that on average it produces lower, and more credible, aboveground biomass estimates at the start of the simulation for these forests (Fig. 5a) and matches the biometric estimates of $\mathrm{C}$ partitioning between leaf and stem (Fig. 8a). The evergreen and deciduous forests appear to allocate carbon differently, and for situations where a fixed scheme is preferred our results favor the adoption of separate schemes for evergreen and deciduous forests. Below we discuss these findings in detail and make some recommendations for future development of allocation schemes. 

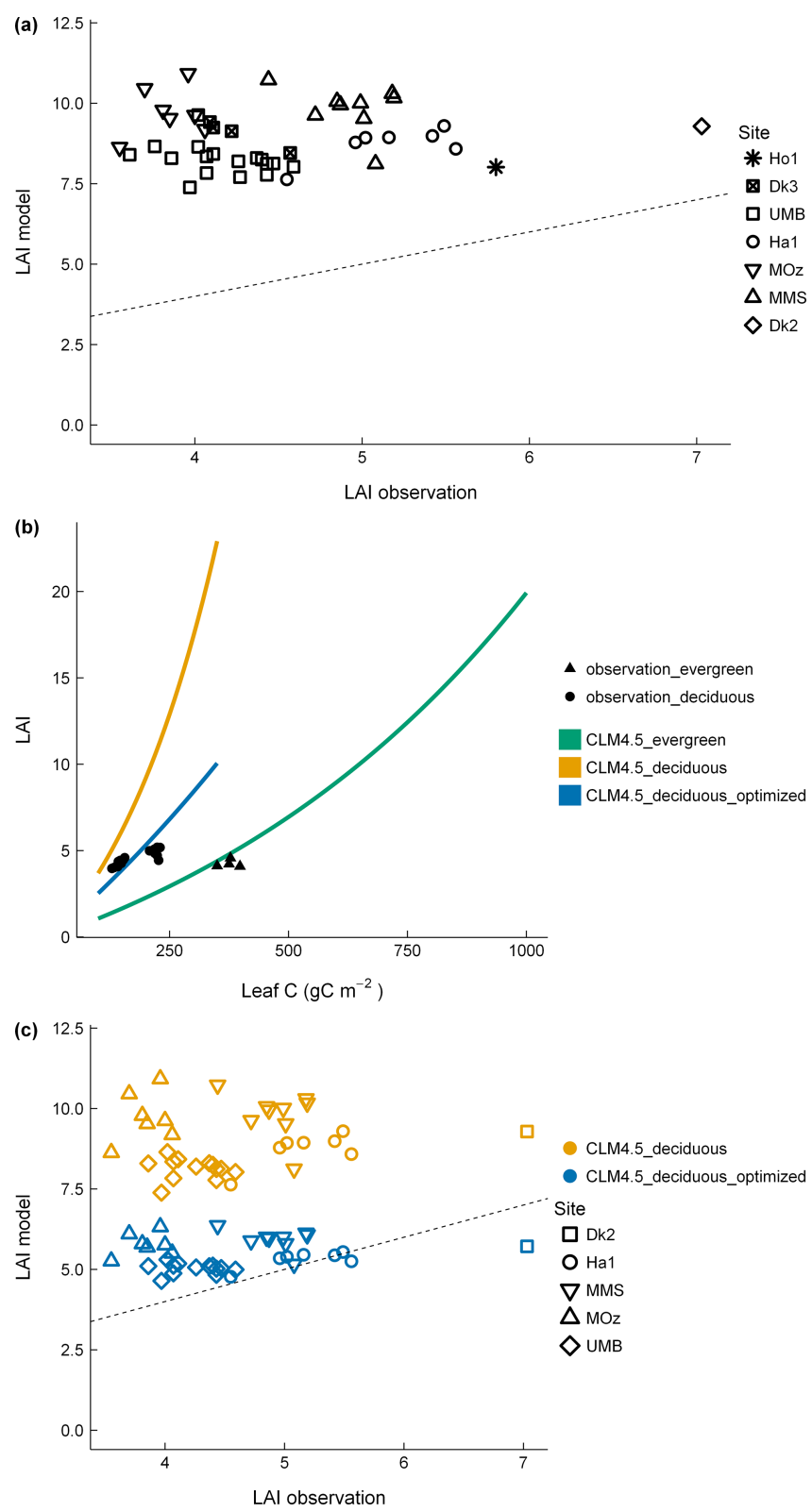

Figure 3. Comparisons between (a) LAI measured in situ and LAI in the model. (b) Relationship between leaf C and LAI in CLM4.5 for deciduous forests, observations for deciduous forests, optimized leaf C-LAI relationship for deciduous forests, CLM4.5 for evergreen forests, and observations for evergreen forests. (c) Comparisons between LAI measured in situ and LAI in the standard and modified version of the model with optimized parameters for LAI. In (a) and (c), dashed line is $1: 1$ relationship between observations and model. Observations (LAI measured in situ and leaf C) are from the AmeriFlux database.

\subsection{C allocation scheme: implications for $\mathrm{C}$ flux and LAI}

The $\mathrm{C}$ allocation scheme does not strongly influence annual GPP, ecosystem respiration, and NEE over 34 years of accu-

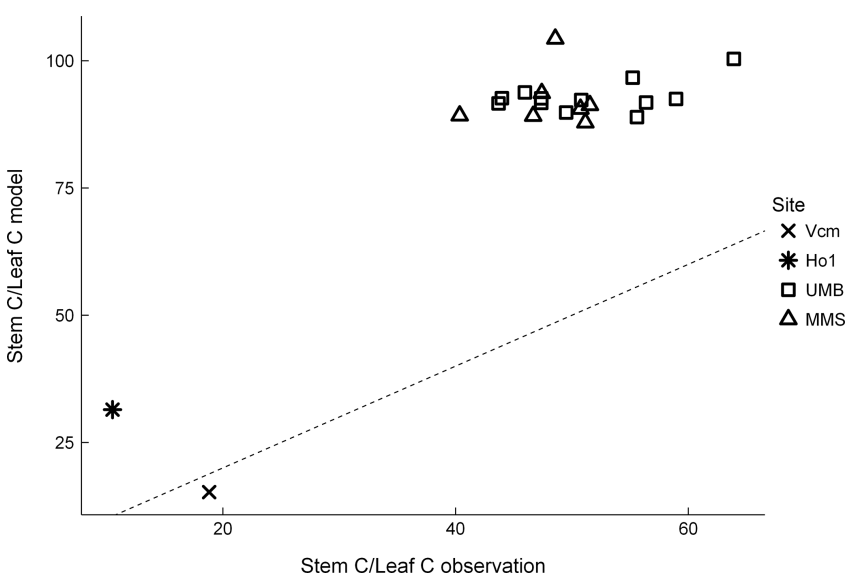

Figure 4. Comparisons between $C_{\text {stem }} / C_{\text {leaf }}$ ratio for the DCLM4.5 scheme and AmeriFlux observations. Dashed line is $1: 1$ relationship between observations and model. Observations ( $C_{\text {stem }}$ and $C_{\text {leaf }}$ ) are from the AmeriFlux database.

mulated effect (Fig. S2 in the Supplement); the overestimation of GPP and ecosystem respiration in Fig. 1 was common to all allocation schemes. GPP was also overestimated in previous versions of CLM (Bonan et al., 2011; Lawrence et al., 2011). Despite revisions of the model structure in previous versions of CLM, and that the GPP bias was found to be most pronounced in the tropics (Lawrence et al., 2011), our results show that the GPP is still overestimated in temperate forests with CLM4.5. Our results support the recommendation by Thornton and Zimmerman (2007) that additional measurements are required to establish the variability of SLA $(x)$ within and between PFTs. Maximum LAI values reported for temperate evergreen and deciduous forests are 15 and 8.8, respectively (Asner et al., 2003). Realistic C allocation schemes (e.g., Litton et al., 2007; Luyssaert et al., 2007) in CLM4.5 combined with the default values for the parameters $\mathrm{SLA}_{0}$ and $m$ resulted in unrealistically high - sometimes $>20$ - estimates of maximum annual LAI values when implementing alternative $\mathrm{C}$ allocation schemes in CLM4.5. When using the optimized parameters in conjunction with the alternative allocation schemes, LAI always remained below 10. Clear and persistent model-data discrepancies in LAI also needed to be addressed in the ORCHIDEE LSM prior to any evaluation of model changes (Thum et al., 2017). Site-specific estimates of SLA and LAI would be very useful for optimizing parameters within their observed range and allow mechanistic processes controlling allocation to leaves in the model to be assessed.

\subsection{C allocation scheme: implications for $\mathrm{C}$ pools}

None of the allocation schemes simultaneously matched observed evergreen and deciduous forest aboveground biomass. D-CLM4.5 underestimated the modeled aboveground biomass for evergreen sites with mean annual 

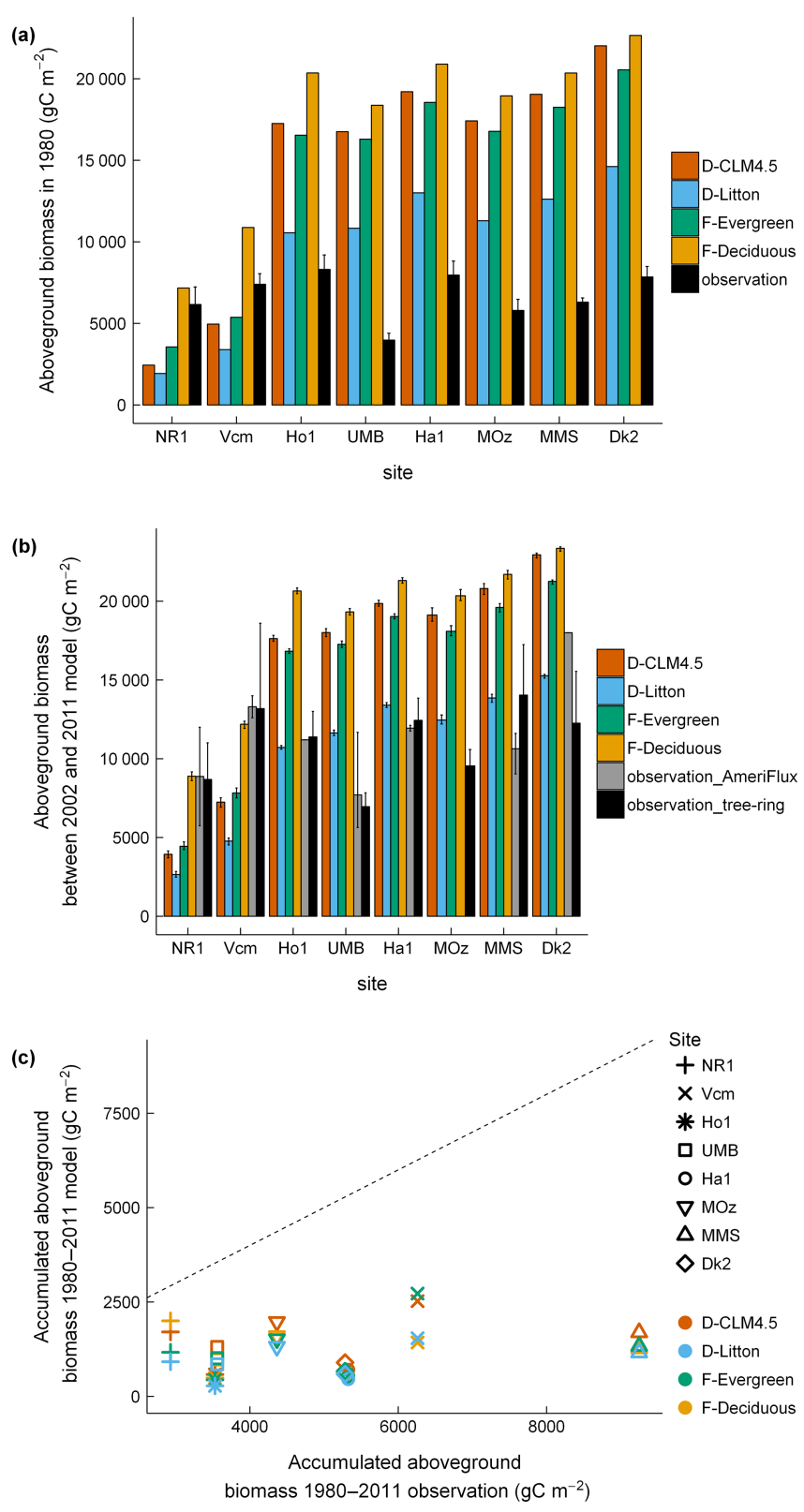

Figure 5. (a) Comparisons between observed and modeled aboveground biomass in 1980 for the four C allocation schemes. (b) Comparisons between mean observed and modeled aboveground biomass between 2002 and 2011 for the four C allocation schemes. (c) Comparisons between observed and modeled accumulated aboveground biomass 1980-2011 for the four C allocation schemes. Turnover rate for stem in CLM4.5 is $2 \%$. Dashed line is $1: 1$ relationship between observations and model. Observations ("observation" in a, "observation_tree_ring" in b, and "accumulated aboveground biomass 1980-2011 observation" in c) are aboveground biomass estimates from tree-ring data, which are from Dye et al. (2016) for the Hal and Hol sites and following the methodology in Alexander et al. (2017) for the rest of sites. Observations ("Observation_AmeriFlux" in b) are aboveground biomass data from the AmeriFlux database, available only for a subset of sites and years (see Table 1).

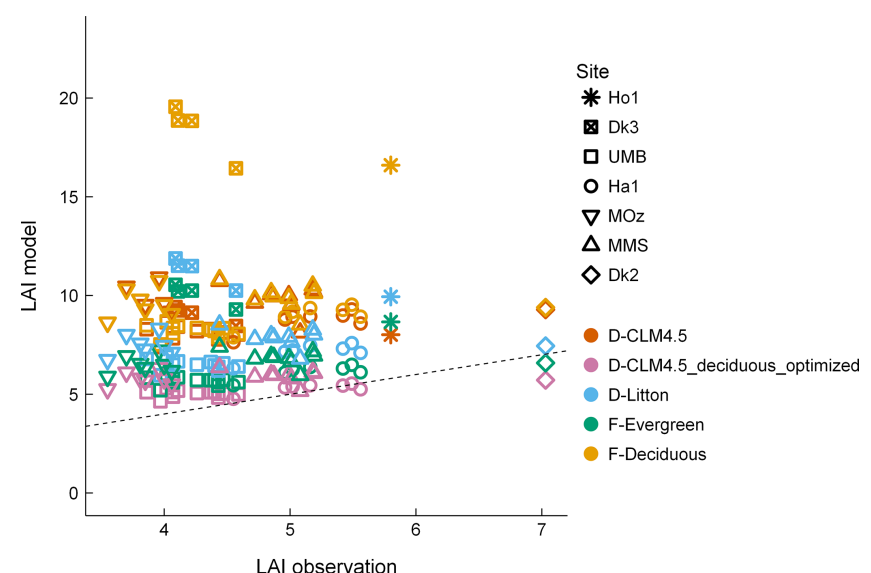

Figure 6. Comparisons between LAI measured in situ and LAI in the model for the different $\mathrm{C}$ allocation schemes (DCLM4.5_deciduous_optimized refers to the one with the optimized leaf C-LAI relationship for deciduous forests in D-CLM4.5). Dashed line is $1: 1$ relationship between observations and model. Observations (LAI measured in situ) are from the AmeriFlux database.

$\mathrm{NPP}<500 \mathrm{~g} \mathrm{C} \mathrm{m}^{-2} \mathrm{yr}^{-1}$, but overestimated it for deciduous sites. These results are in line with previous findings in evergreen Oregon forests where CLM4.0 also underestimated aboveground biomass at most sites (Hudiburg et al., 2013). The strong overestimation in biomass at temperate deciduous sites is due to the fact these sites had a higher mean annual NPP and therefore a higher allocation to stem in D-CLM4.5 than the evergreen sites. A similar pattern has been found in other models, in which a high allocation to stem results in an overestimation of aboveground biomass (e.g., Song et al., 2016). In a comparison between observations and CMIP5 Earth system models for tropical forests, the high CLM-based biomass values were attributed to the high stem allocation relative to observations (Negron-Juarez et al., 2015). D-CLM4.5 stem C allocation has a value of $\sim 46 \%$ when annual NPP is close to or greater than $1000 \mathrm{~g} \mathrm{C} \mathrm{m}^{-2} \mathrm{yr}^{-1}$, while forest data syntheses indicate that $20-35 \%$ are more plausible for sites with similar mean annual NPP to our sites (Litton et al., 2007). Other LSMs have an even higher allocation to stem of 45$50 \%$ for temperate forests (Table 3; Ise et al., 2010; Xia et al., 2015). Our results show that an alternative scheme (D-Litton, based on Litton et al., 2007), which greatly reduced allocation to stem compared with D-CLM4.5, provided more realistic estimates of aboveground biomass for deciduous sites (Fig. 5a and b). However, the D-CLM4.5-based estimates of aboveground biomass were closer to the observed values than those from the D-Litton scheme for evergreen sites with mean annual $\mathrm{NPP}<500 \mathrm{~g} \mathrm{C} \mathrm{m}^{-2} \mathrm{yr}^{-1}$ (NR1 and $\mathrm{Vcm}$ ). Our results suggest that it is necessary to improve the D-CLM4.5 scheme for temperate forests; for evergreen forests the DLitton scheme could be modified from a linear to a nonlinear 

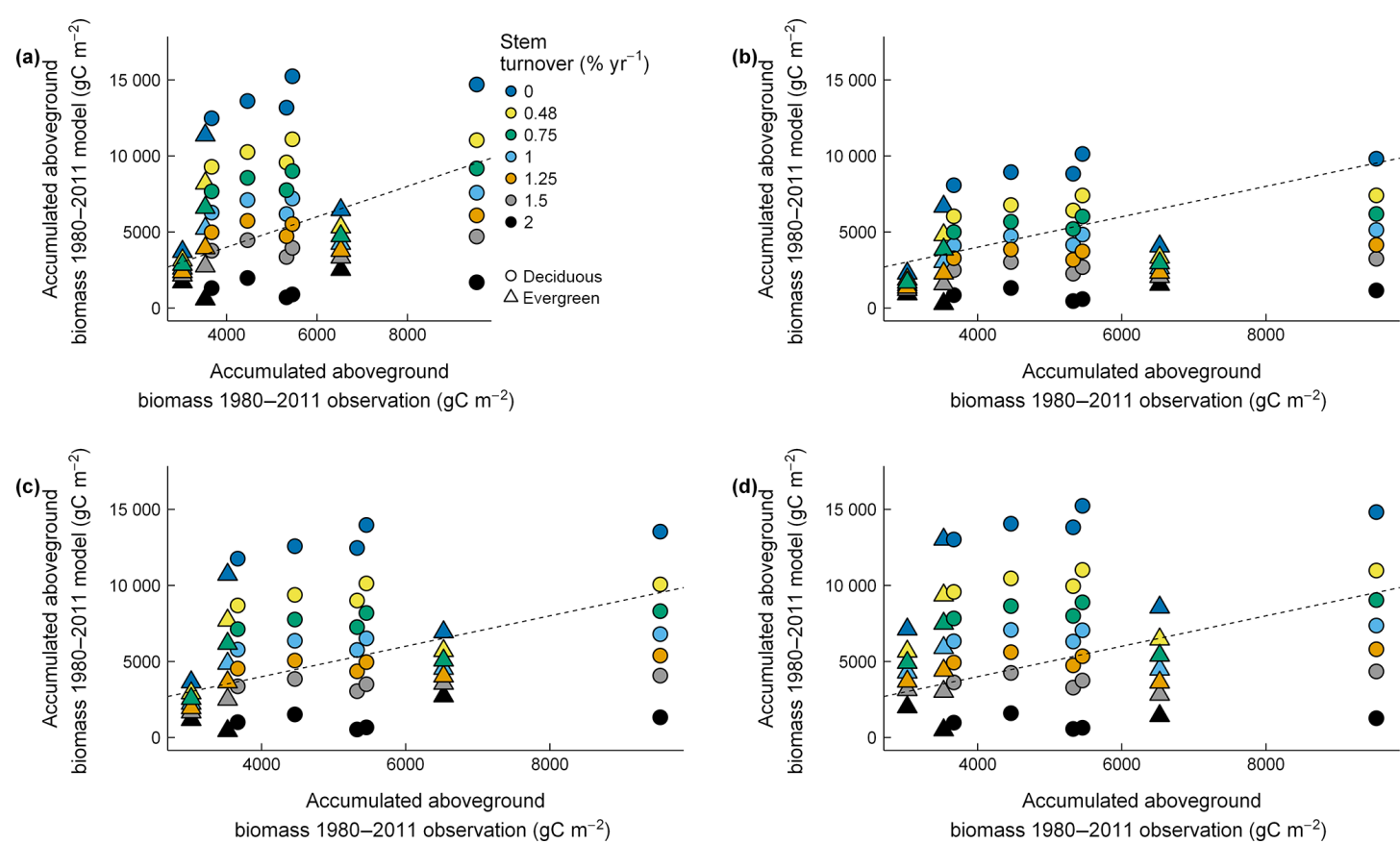

Figure 7. Comparisons between observed and modeled accumulated aboveground biomass 1980-2011 for (a) D-CLM4.5 allocation scheme, (b) D-Litton allocation scheme, (c) F-Evergreen allocation scheme, and (d) F-Deciduous allocation scheme. We assumed different turnover rates for stem from 0 to $2 \% \mathrm{yr}^{-1}$. Turnover rate for stem in the model is $2 \% \mathrm{yr}^{-1}$. Dashed line is $1: 1$ relationship between observations and model. Observations (aboveground biomass estimates from tree-ring data) are from Dye et al. (2016) for the Ha1 and Ho1 sites and following the methodology in Alexander et al. (2017) for the rest of sites.
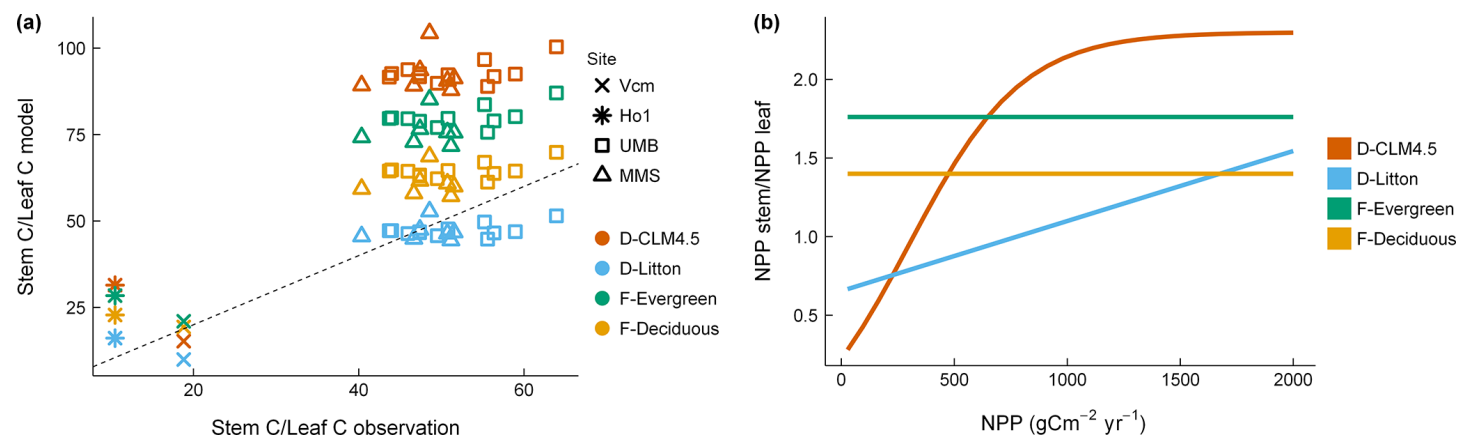

Figure 8. (a) Comparisons between $C_{\text {stem }} / C_{\text {leaf }}$ ratio for the four $\mathrm{C}$ allocation schemes and AmeriFlux observations. $(\mathbf{b}) \mathrm{NPP}_{\text {stem }} / \mathrm{NPP}_{\text {leaf }}$ ratio for the different mean annual NPP values and $\mathrm{C}$ allocation schemes. In Fig. 8a, dashed line is $1: 1$ relationship between observations and model. Observations $\left(C_{\text {stem }}\right.$ and $\left.C_{\text {leaf }}\right)$ are from the AmeriFlux database.

scheme to increase allocation to stem for sites with mean annual NPP $<500 \mathrm{~g} \mathrm{C} \mathrm{m}^{-2} \mathrm{yr}^{-1}$.

LSMs tend to overestimate allocation to stem in temperate forest syntheses and therefore underestimate allocation to leaves. C allocation to leaf in D-CLM4.5 is probably underestimated when mean annual NPP is relatively close to or greater than $1000 \mathrm{~g} \mathrm{C} \mathrm{m}^{-2} \mathrm{yr}^{-1}$. In other LSMs carbon allocation to leaf shows broad ranges $(\sim 19-30 \%$; Table 3 ; Ise et al., 2010; Xia et al., 2015). The D-CLM4.5 scheme is dynamic, with changing $\mathrm{C}$, but functions as a fixed scheme at higher NPP values (Fig. S1 in the Supplement), which means that at many sites the allocation to leaf is $20 \%$ in this scheme, which is $\sim 5-10 \%$ lower than available data suggest for deciduous sites (Table 3; Litton et al., 2007; Luyssaert et al., 2007; Wolf et al., 2011). There is reasonable agreement across LSMs on how much carbon is allocated to roots; however, root biomass is difficult to measure accurately and data are sparse. Allocation to root and stem are variable between sites, and conditions that favor high productivity increase partitioning to stem and decrease partitioning to root (Litton et al., 2007). D-CLM4.5 allocates $34-40 \%$ of carbon to roots, which is similar to most other models (Table 3 ). 

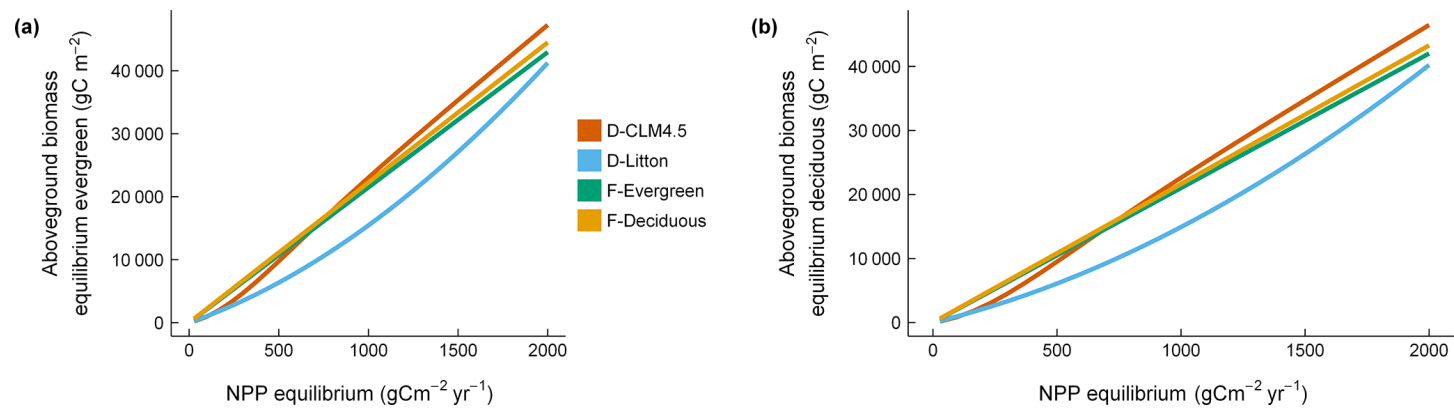

Figure 9. The $\mathrm{C}$ allocation scheme determines aboveground biomass $\mathrm{C}$ at equilibrium for (a) evergreen and (b) deciduous sites. For the deciduous sites, with NPP at equilibrium conditions, the D-Litton allocation scheme is closer to the observed aboveground biomass values in 1980 (see Fig. 5a).

The partitioning between fine and coarse root is absent from most syntheses, but empirical studies show a wide range in allocation of $\mathrm{C}$ belowground and are generally higher than LSMs (Table 3; Nadelhoffer and Raich, 1992; Gower et al., 2001; Newman et al., 2006; Luyssaert et al., 2007; Litton et al., 2007; Wolf et al., 2011; Gill and Finzi, 2016).

Although root function is complex in reality, the controls of root dynamics and function are highly simplified in LSMs (Warren et al., 2015). It has been suggested that resource allocation is controlled by two separate functional trade-offs between leaf or fine roots and their supporting woody organs (Chen et al., 2013). If this is correct, LSMs should use an allocation scheme based on at least two (or probably three) dynamic allometric parameters, instead of the DCLM4.5 which is based only on one dynamic allometric parameter $\left(a_{3}\right)$. Here, we implemented an allocation scheme (D-Litton) that included two dynamic allometric parameters ( $a_{2}$ and $a_{3}$ ) based on Litton et al. (2007), assuming that the ratio between allocation to leaf and fine root $\left(a_{1}\right)$ is constant. However, some studies suggest that this trade-off includes fine roots (Wolf et al., 2011; Malhi et al., 2011; Chen et al., 2013), probably due to the colimitation of productivity by resources captured aboveground (e.g., light) and belowground (e.g., nutrients and water; Dybzinski et al., 2011; Weng et al., 2016). These growth drivers also vary with time and across spatial ecological gradients (Guillemot et al., 2015). In CLM4.5 employed here, the roots control water uptake but are not related to nutrient uptake, which limits the potential for dynamic responses to nutrients and $\mathrm{CO}_{2}$ concentrations (Atkin, 2016; De Kauwe et al., 2014; Hickler et al., 2015; Sevanto and Dickman 2015). Root functionality in LSMs could be enhanced by improving parameterization within models and introducing new components such as dynamic root distribution and root functional traits linked to resource extraction (Warren et al., 2015; Brzostek et al., 2014, 2017; Shi et al., 2016; Phillips et al., 2016; Iversen et al., 2017).

\subsection{C allocation scheme: implications for steady-state aboveground biomass}

Initial conditions used to begin transient runs or make forecasts in LSMs are usually obtained by spin-up methods. Starting from bare ground, with prescribed physical soil characteristics and plant functional type fractions, a time series of meteorological forcing variables are cycled repeatedly until the model reaches a steady state, a point when $\mathrm{C}$ pool sizes and fluxes remain constant between subsequent meteorological forcing cycles. This feature is exploited by Xia et al. (2012) with their semi-analytical approach to calculating these steady-state conditions. Model simulations over timescales from days to centuries critically depend on the initial variable values obtained after spin-up, and flawed initial values may produce model output that can be severely biased or unrealistic (Yang et al., 1995; Cosgrove et al., 2003; Rodell et al., 2005; Li et al., 2009). There is an increasing awareness in Earth system modeling of the critical role of these initial values after spin-up (including the initialized size of C pools - examined in 2017) that adds an extra layer of complexity in diagnosing the impact of an incorrect representation of physical processes on the transient simulation (Kay et al., 2015; Fisher et al., 2015). Our results reinforce that concern by showing that with the same climate forcing different $\mathrm{C}$ allocation schemes within the same LSM can produce strongly differing initial conditions after spin-up for aboveground biomass (Fig. 9). In the Supplement "Methods and Figures", we provide an explanation for the variability in steady-state aboveground biomass depending on the $\mathrm{C}$ allocation scheme used in CLM4.5. In the $\mathrm{C}$ allocation schemes used, changing biomass with time can be expressed as Eq. (4), which are models that behave as a linear autonomous system (Sierra et al., 2017). This implies the models, when forced with equivalent meteorology and physical soil properties, will eventually converge to a steady-state independent of the starting values of the state variables, although in the case of CLM this may take many tens of thousands of years. 


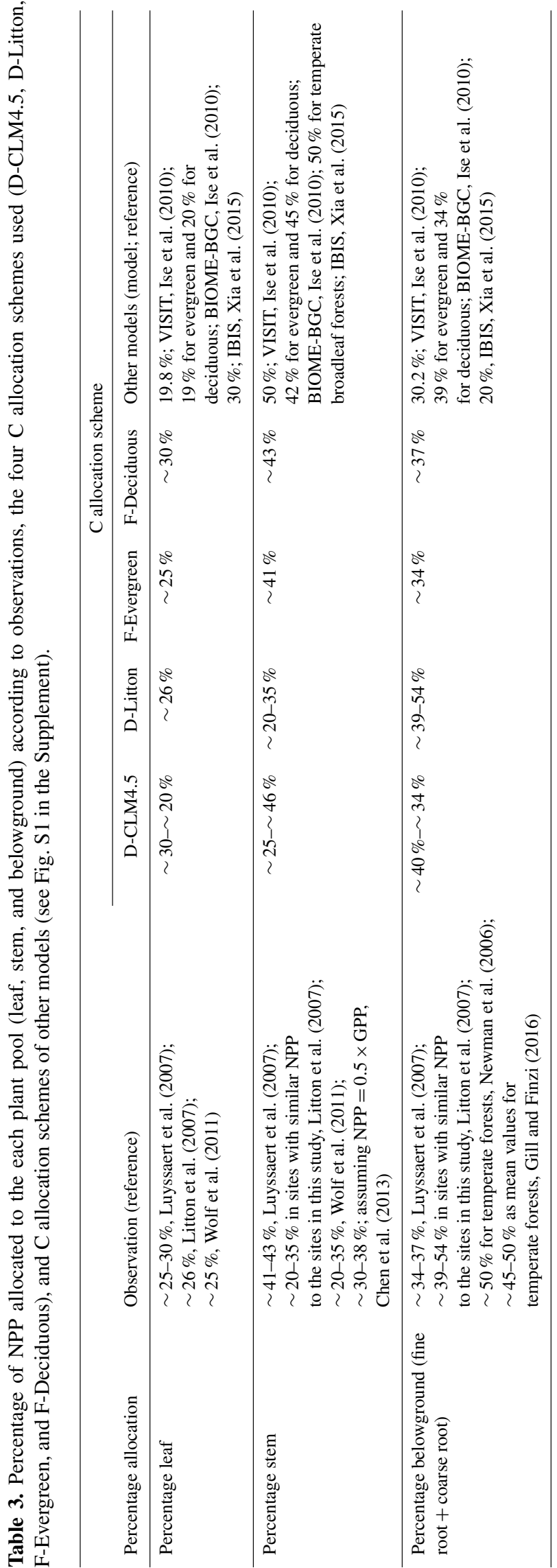

\subsection{C allocation scheme: implications of the $\mathbf{N P P}_{\text {stem }} / \mathbf{N P P}_{\text {leaf }}$ ratio}

The NPP stem $/ \mathrm{NPP}_{\text {leaf }}$ ratio in the model ( $a_{3}$ parameter) is one of the primary factors contributing to overestimations of biomass. While the $\mathrm{D}$-Litton scheme best approximates the average ratio of stem $\mathrm{C}$ to leaf $\mathrm{C}$, realistic $\mathrm{C}_{\text {stem }} / \mathrm{C}_{\text {leaf }}$ ratios are produced in CLM4.5 at sites where the D-CLM4.5 $\mathrm{NPP}_{\text {stem }} / \mathrm{NPP}_{\text {leaf }}$ ratio is similar to the values in the D-Litton scheme (Fig. 8). Any overestimation of allocation to stem is compounded because stem $\mathrm{C}$ has a longer turnover time than leaf C (Schulze et al., 2000; Xia et al., 2015; Song et al., 2016). Overestimation of allocation to stem was also found using the IBIS model, where a fixed allocation scheme with terms for allocation to leaf, stem, and root, which sum to 1, was found to overestimate allocation to stem (Xia et al., 2015). The fractional allocation to stem in IBIS was reduced from 0.5 to 0.36 when the scheme was optimized against satellite LAI observations (Xia et al., 2015). Similarly, our results suggest that allocation to stem in D-CLM4.5 should decrease and allocation to leaf and root should increase, to match observed biomass.

\subsection{C allocation scheme and stem turnover rate: implications for accumulated aboveground biomass}

Regardless of allocation scheme, CLM4.5 overestimates aboveground NPP and underestimates aboveground biomass increments (Fig. 5c), this suggests that the stem turnover rate is overestimated in the model. The underestimation of increment can be attributed to an inaccurate representation of production in the model, an inaccurate representation of turnover time of the plant pools, or both (Friend et al., 2014; Koven et al., 2015). Aboveground NPP in the D-CLM4.5 scheme from the deciduous sites, including UMBS, Morgan Monroe, Harvard Forest, and Duke hardwoods (Megonigal et al., 1997; Curtis et al., 2002) was consistently higher than that in the observations. The D-Litton scheme, however, resulted in aboveground NPP estimations that were consistently closer to the observations (data not shown). These results suggest that, in temperate deciduous forests, the D-CLM4.5 scheme is overestimating allocation to stem and underestimating allocation to roots, as previously found in other models like IBIS (Xia et al., 2015).

It is likely that CLM4.5 overestimates stem turnover at these sites. Currently, CLM4.5 assumes a stem mortality rate of $2 \% \mathrm{yr}^{-1}$ that is higher than published tree mortality rates for forests in the USA (van Mantgem et al., 2009; Brown and Schroeder, 1999; Runkle, 1998). When considering large geographic scales the $2 \% \mathrm{yr}^{-1}$ rate of stem turnover may be reasonable, but at individual sites this may be a poor approximation. The Harvard Forest, for example, is at the end of the stem exclusions stage of forest development, and there has been little to no canopy disturbance since the time of the 1969 census. As such, the tree-ring biomass incre- 
ment estimates at Harvard assume zero mortality between 1980 and 2012. This assumption appears solid as it results in no significant difference between tree-ring reconstructed biomass increment and the repeated measurements from permanent plots over the last 40 years (Dye et al., 2016). We thus decreased the stem mortality rate from $2 \% \mathrm{yr}^{-1}$ to published ranges of tree mortality (between 0 and $1.5 \% \mathrm{yr}^{-1}$ ), to estimate plausible stem turnover rates for each site and scheme. The resulting ranges of aboveground biomass increment overlapped with the observed aboveground biomass increment estimated from tree-ring data, for nearly all the carbon allocation schemes (see Fig. 7). For Harvard forest the turnover rate that was most consistent with the tree-ring reconstruction was never zero, which indicates that both NPP and turnover are overestimated for this site in all the allocation schemes. A different turnover rate was required for each site and $\mathrm{C}$ allocation scheme to match the observed aboveground biomass increment, but in each case it was below the default $2 \%$ value. Our analysis suggests that when using AmeriFlux sites to inform models, or other site-level observations, taking note of site-specific rates of stem turnover is prudent.

Given the high uncertainty associated with turnover relative to production, it has been suggested that research priorities should move from production to turnover (Friend et al., 2014). Our results show the need for improvements of models in carbon turnover processes, a current limitation in stateof-the-art LSMs (Thurner et al., 2017). Tree-ring widths can provide reliable estimates of biomass increment, but repeated surveys of forests are required to estimate stem turnover in nonequilibrium stands (Alexander et al., 2017; Dye et al., 2016; Klesse et al., 2016; Babst et al., 2014). However, whole-ecosystem $\mathrm{C}$ turnover will encompass processes other than mortality, including disturbances and land-use and landcover change (Masek et al., 2008; Erb et al., 2016; Thurner et al., 2017). Some of the aforementioned processes are already partially incorporated in LSMs, in particular land-use and land-cover change, but the lack of a mechanistic representation of the remaining processes is therefore indirectly represented in stem turnover rates. The processes controlling turnover times influence $\mathrm{C}$ storage capacity, but turnover is not well constrained in models (Friend et al., 2014; Chen et al., 2015; Sierra et al 2017).

\section{Conclusions and perspectives}

Our results highlight the importance of evaluating the $\mathrm{C}$ allocation scheme and the stem turnover in LSMs using measures of $\mathrm{C}$ stocks in addition to flux data. The four $\mathrm{C}$ allocation schemes translated to important long-term differences in $\mathrm{C}$ accumulation in aboveground biomass, but gave similar results for short-term $\mathrm{C}$ fluxes. We were unable to distinguish between the allocation schemes using eddy flux data alone.
Data on different carbon pools are sparse, but very useful in parameterizing allocation schemes. We found that sitespecific SLA was a prerequisite to evaluating the different allocation schemes; large-scale databases might be exploited to better estimate this relationship. Fixed allocation schemes preclude dynamic changes in allocation in response to varying water and nutrient availability on seasonal to interannual timescales (De Kauwe et al., 2014), but they have the advantage of simplicity. If fixed allocation schemes are used in land surface modeling, we suggest different schemes for evergreen and deciduous forests and that databases like Litton et al. (2007) and Luyssaert et al. (2007) can be used to parameterize them.

Finally, we show that information on stem turnover rate, which varies with forest age and successional status, is important to interpret the success or failure of different model schemes at forest sites. Stem turnover in CLM4.5 may approximate steady-state conditions on large scales, and so is inconsistent with forests which are not at steady state. Decreasing the stem turnover rate from $2 \% \mathrm{yr}^{-1}$ to plausible values consistent with their successional status yielded aboveground biomass accumulation rates consistent with observations. It is possible to estimate equilibrium turnover rates from mean stand age derived from tree-ring estimates; this could be a promising technique to approximate the duration of carbon storage in temperate forests, though equilibrium assumptions are problematic.

Ecological theory suggests that dynamic allocation probably reflects whatever resource is most limiting, but developing allocation schemes for LSMs that respond to resource limitation is challenging. The two dynamic allocation schemes reflect forest stand development to some extent, i.e., as trees get bigger (and can grow more) they tend to invest more in stem and less in leaves. However, the two schemes both use low NPP, regardless of cause, as a proxy for resource limitation (Fig. S1 in the Supplement). Cohort representation in the model would enable ontogenetic changes in allocation but would not avoid the problem that these dynamic schemes cause sites with low average NPP to perpetually allocate more resources to leaves and roots, while sites with high average NPP perpetually allocate less resources to leaves and roots (Fig. S1 in the Supplement). As coupled C-N and functional root subroutines are developed for LSMs (Shi et al., 2016), and with better representation of vegetation dynamics (Fisher et al., 2015), we could imagine a dynamic allocation scheme for CLM4.5 based on whether aboveground (light) or belowground (water and nutrients) factors are limiting.

Code availability. The code for CLM version 4.5 (CLM4.5) is available at https://svn-ccsm-models.cgd.ucar.edu/cesm1/release_ tags/cesm1_2_1 (registration required at: http://www.cesm.ucar. edu/models/register/register.html). The allometric parameters used for the different $\mathrm{C}$ allocation schemes used in this study with CLM4.5 are shown in Table 2. The code modifications and pa- 
rameter files for this paper are available from https:/github.com/ davidjpmoore/gmd-2017-74.

Data availability. The data for this paper are available upon request to the corresponding author.

\section{The Supplement related to this article is available online at https://doi.org/10.5194/gmd-10-3499-2017- supplement.}

Competing interests. The authors declare that they have no conflict of interest.

Acknowledgements. This study was supported by the DOE Regional and Global Climate Modeling DE-SC0016011, the NSF Macrosystems Award 1241851 and 1241930 and by the University of Arizona Water, Environment, and Energy Solutions (WEES) 578 and Sustainability of Semi-Arid Hydrology and Riparian Areas (SAHRA) programs. The US-NR1, US-UMB, and US-MMS AmeriFlux sites are currently supported by the US DOE, Office of Science, through the AmeriFlux Management Project (AMP) at Lawrence Berkeley National Laboratory under award numbers 7094866, 7096915, and 7068666, respectively. AmeriFlux site US-MOz is supported by the US Department of Energy, Office of Science, Office of Biological and Environmental Research Program, through Oak Ridge National Laboratory's Terrestrial Ecosystem Science (TES) Science Focus Area (SFA). ORNL is managed by UT-Battelle, LLC, for the US DOE under contract DE-AC05-00OR22725. Flurin Babst acknowledges funding from the Swiss National Science Foundation (no. P300P2_154543) and the EU-Horizon 2020 Project "BACI" (no. 640176).

Edited by: Carlos Sierra

Reviewed by: two anonymous referees

\section{References}

Alexander, R. M., Rollinson, C. R., Babst, F., Trouet, V., and Moore, D. J. P.: Uncertainty in tree-ring based aboveground biomass estimates does not substantially alter growth-climate relationships, Trees-Struct. Funct., in review, 2017.

Asner, G. P., Scurlock, J. M., and Hicke, J. A.: Global synthesis of leaf area index observations: implications for ecological and remote sensing studies, Global Ecol. Biogeogr., 12, 191-205, 2003.

Atkin, O.: New Phytologist: bridging the 'plant function-climate modelling divide', New Phytol., 209, 1329-1332, 2016.

Babst, F., Bouriaud, O., Papale, D., Gielen, B., Janssens, I. A., Nikinmaa, E., Ibrom, A., Wu, J., Bernhofer, C., Köstner, B., Grünwald, T., Seufert, G., Ciais, P., and Frank, D.: Above-ground woody carbon sequestration measured from tree rings is coherent with net ecosystem productivity at five eddy-covariance sites, New Phytol., 201, 1289-1303, 2014.
Baldocchi, D., Falge, E., Gu, L., Olson, R., Hollinger, D., Running, S., Anthoni, P., Bernhofer, C., Davis, K., Evans, R., Fuentes, J., Goldstein, A., Katul, G., Law, B., Lee, X., Malhi, Y., Meyers, T., Munger, W., Oechel, W., Paw, U. K. T., Pilegaard, K., Schmid, H. P., Valentini, R., Verma, S., Vesala, T., Wilson, K., and Wofsy, S.: FLUXNET: a new tool to study the temporal and spatial variability of ecosystem-scale carbon dioxide, water vapor, and energy flux densities, B. Am. Meteor. Soc., 82, 2415-2434, 2001.

Baldocchi, D., Ryu, Y., and Keenan, T.: Terrestrial Carbon Cycle Variability [version 1; referees: 2 approved] F1000Research 2016, 5(F1000 Faculty Rev):2371, https://doi.org/10.12688/f1000research.8962.1, 2016.

Blanken, P.: AmeriFlux US-NR1 Niwot Ridge Forest (LTER NWT1), https://doi.org/10.17190/AMF/1246088, 2016.

Bloom, A. A., Exbrayat, J. F., van der Velde, I. R., Feng, L., and Williams, M.: The decadal state of the terrestrial carbon cycle: global retrievals of terrestrial carbon allocation, pools, and residence times, P. Natl. Acad. Sci., 113, 1285-1290, 2016.

Boden, T. A., Krassovski, M., and Yang, B.: The AmeriFlux data activity and data system: an evolving collection of data management techniques, tools, products and services, Geosci. Instrum. Method. Data Syst., 2, 165-176, https://doi.org/10.5194/gi-2165-2013, 2013.

Bonan, G. B.: Forests and climate change: forcings, feedbacks, and the climate benefits of forests, Science, 320, 1444-1449, 2008.

Bonan, G. B., Lawrence, P. J., Oleson, K. W., Levis, S., Jung, M., Reichstein, M., Lawrence, D. M., and Swenson, S. C.: Improving canopy processes in the Community Land Model version 4 (CLM4) using global flux fields empirically inferred from FLUXNET data, J. Geophys. Res., 116, G02014, https://doi.org/10.1029/2010JG001593, 2011.

Brown, S.: Measuring carbon in forests: current status and future challenges. Environ. Pollut., 116, 363-372, 2002.

Brown, S. L. and Schroeder, P. E.: Spatial patterns of aboveground production and moratlity of woody biomass for Eastern U.S. forests, Ecol. Appl., 9, 968-980, 1999.

Brzostek, E. R., Fisher, J. B., and Phillips, R. B.: Modeling the carbon cost of plant nitrogen acquisition: mycorrhizal tradeoffs and multipath resistance uptake improve predictions of retranslocation, J. Geophys. Res.-Biogeosci., 119, 1684-1697, https://doi.org/10.1002/2014JG002660, 2014.

Brzostek, E. R., Rebel, K. T., Smith, K. R., and Phillips, R. P.: Integrating mycorrhizae into global scale models: a journey toward relevance in the Earth's climate system. In: Johnson, N.C., Gehring, C., and Jansa, J. Eds. Mycorrhizal mediation of soil: fertility, structure, and carbon storage, Elsevier, 479-499, 2017.

Caspersen, J. P., Pacala, S. W., Jenkins, J. C., Hurtt, G. C., Moorcroft, P. R., and Birdsey, R. A.: Contributions of land-use history to carbon accumulation in US forests, Science, 290, 1148-1151, 2000.

Chen, G., Yang, Y., and Robinson, D.: Allocation of gross primary production in forest ecosystems: allometric constraints and environmental responses, New Phytol., 200, 1176-1186, 2013.

Chen, M., Melaas, E. K., Gray, J. M., Friedl, M. A., and Richardson, A. D.: A new seasonal-deciduous spring phenology submodel in the Community Land Model 4.5: impacts on carbon and water cycling under future climate scenarios, Global Chang. Biol., 22, 3675-3688, 2016 
Chen, Y., Xia, J., Sun, Z., Li, J., Luo, Y., Gang, C., and Wang, Z.: The role of residence time in diagnostic models of global carbon storage capacity: model decomposition based on a traceable scheme, Sci. Rep., 5, 16155, https://doi.org/10.1038/srep16155, 2015.

Chojnacky, D. C., Heath, L. S., and Jenkins, J. C.: Updated generalized biomass equations for North American tree species, Forestry, 87, 129-151, 2014.

Cosgrove, B. A., Lohmann, D., Mitchell, K. E., Houser, P. R., Wood, E. F., Schaake, J. C., Robock, A., Sheffield, J., Duan, Q., Luo, L., Higging, R. W., Pinker, R. T., and Tarpley, J. D.: Land surface model spin-up behavior in the North American Land Data Assimilation System (NLDAS), J. Geophys. Res., 108, 8845, https://doi.org/10.1029/2002JD003316, 2003.

Cottam, G., Curtis, J. T., and Hale, B. W.: Some sampling characteristics of a population of randomly dispersed individuals, Ecology, 34, 741-757, 1953.

Curtis, P. S., Hanson, P. J., Bolstad, P., Barford, C., Randolph, J. C., Schmid, H. P., and Wilson, K. B.: Biometric and eddy-covariance based estimates of annual carbon storage in five eastern North American deciduous forests, Agr. Forest Meteorol., 113, 3-19, 2002.

De Kauwe, M. G., Medlyn, B. E., Zaehle, S., Walker, A. P., Dietze, M. C., Wang, Y.-P., Luo, Y., Jain, A. K., El-Masri, B., Hickler, T., Warlind, D., Weng, E., Parton, W. J., Thornton, P. E., Wang, S., Prentice, I. C., Asao, S., Smith, B., McCarthy, H. R., Iversen, C. M., Hanson, P. J., Warren, J. M., Oren, R., and Norby, R. J.: Where does the carbon go? A model-data intercomparison of vegetation carbon allocation and turnover processes at two temperate forest free-air $\mathrm{CO}_{2}$ enrichment sites, New Phytol., 203, 883-899, 2014.

Delbart, N., Ciais, P., Chave, J., Viovy, N., Malhi, Y., and Le Toan, T.: Mortality as a key driver of the spatial distribution of aboveground biomass in Amazonian forest: results from a dynamic vegetation model, Biogeosciences, 7, 3027-3039, https://doi.org/10.5194/bg-7-3027-2010, 2010.

Douglass, A. E.: Crossdating in dendrochronology, J. Forest., 39, 825-831, 1941.

Dybzinski, R., Farrior, C., Wolf, A., Reich, P. B., and Pacala, S. W.: Evolutionarily stable strategy carbon allocation to foliage, wood, and fine roots in trees competing light and nitrogen: an analytically tractable, individual-based model and quantitative comparisons to data, Am. Nat., 177, 153-166, 2011.

Dye, A., Barker Plotkin, A., Bishop, D., Pederson, N., Poulter, B., and Hessl, A.: Comparing tree-ring and permanent plot estimates of aboveground net primary production in three eastern U.S. forests, Ecosphere, 7, e01454, https://doi.org/10.1002/ecs2.1454, 2016.

Erb, K.-E., Fetzel, T., Plutzar, C., Kastner, T., Lauk, C., Mayer, A., Niedertscheider, M., Körner, C., and Haber, H.: Biomass turnover time in terrestrial ecosystems halved by land use, Nat. Geosci., 9, 674-678, 2016.

Fisher, R. A., Muszala, S., Verteinstein, M., Lawrence, P., Xu, C., McDowell, N. G., Knox, R. G., Koven, C., Holm, J., Rogers, B. M., Spessa, A., Lawrence, D., and Bonan, G.: Taking off the training wheels: the properties of a dynamic vegetation model without climate envelopes, CLM4.5(ED), Geosci. Model Dev., 8, 3593-3619, https://doi.org/10.5194/gmd-8-3593-2015, 2015.
Friend, A. D., Arneth, A., Kiang, N. Y., Lomas, M., Ogée, J., Rödenbeck, C., Running, S. W., Santaren, J.-D., Sitch, S., Viovy, N., Woodward, F. I., and Zaehle, S.: FLUXNET and modeling the global carbon cycle, Glob. Change Biol., 13, 610-633, 2007.

Friend, A. D., Lucht, W., Rademacher, T. T., Keribin, R., Betts, R., Cadule, P., Ciais, P., Clark, D. B., Dankers, R., Falloon, P. D., Ito, A., Kahana, R., Kleidon, A., Lomas, M. R., Nishina, K., Ostberg, S., Pavlick, R., Peylin, P., Schaphoff, S., Vuichard, N., Warszawski, L., Wiltshire, A., and Woodward, F. I.: Carbon residence time dominates uncertainty in terrestrial vegetation responses to future climate and atmospheric $\mathrm{CO}_{2}$, P. Natl. Acad. Sci., 111, 3280-3285, 2014.

Gifford, R. M.: Plant respiration in productivity models: conceptualisation, representation, and issues for global-terrestrial carboncycle research, Funct. Plant Biol., 30, 171-186, 2003.

Gill, A. I. and Finzi, A. C.: Belowground carbon flux links biogeochemical cycles and resource-use efficiency at the global scale, Ecol. Lett., 19, 1419-1428, 2016.

Gough, C. M., Flower, C., Volgel, C. S., Dragoni, D., and Curtis, P. S.: Whole ecosystem labile carbon production in a north temperate deciduous forest, Agr. Forest Meteorol., 149, 1531-1540, 2009.

Gough, C. M., Hardiman, B. S., Nave, L. E., Bohrer, G., Maurer, K. D., Vogel, C. S., Nadelhoffer, K. J., and Curtis, P. S.: Sustained carbon uptake and storage following moderate disturbance in a Greta Lakes forest, Ecol. Appl., 23, 1202-1215, 2013.

Gough, C. M., Bohrer, G., and Curtis, P. S.: AmeriFlux US-UMB University of Michigan Biological Station, https://doi.org/10.17190/AMF/1246107, 2016.

Gower, S. T., Krankina, O., Olson, R. J., Apps, M., Linder, S., and Wang, C.: Net primary production and carbon allocation patterns of boreal forests ecosystems, Ecol. Appl., 11, 1395-1411, 2001.

Grissino-Mayer, H. D.: Evaluating crossdating accuracy: a manual and tutorial for the computer program COFECHA, Tree-Ring Res., 57, 205-221, 2001.

Guillemot, J., Martin-StPaul, N. K., Dufrêne, E., François, C., Soudani, K., Ourcival, J. M., and Delpierre, N.: The dynamic of the annual carbon allocation to wood in European tree species is consistent with a combined source-sink limitation of growth: implications for modelling, Biogeosciences, 12, 2773-2790, https://doi.org/10.5194/bg-12-2773-2015, 2015.

Hickler, T., Rammig, A., and Werner, C.: Modelling $\mathrm{CO}_{2}$ impacts on forest productivity, Current Forestry Reports, 1, 69-80, 2015.

Hollinger, D.: AmeriFlux US-Ho1 Howland Forest (main tower), http://ameriflux.lbl.gov/doi/AmeriFlux/US-Ho1, 2016.

Holmes, R. L.: Computer-assisted quality control in tree-ring dating and measurement, Tree-Ring Bull., 43, 69-78, 1983.

Houghton, R. A.: Aboveground forest biomass and the global carbon balance, Glob. Change Biol., 11, 945-958, 2005.

Hudiburg, T. W., Law, B. E., and Thornton, P. E.: Evaluation and improvement of the Community Land Model (CLM4) in Oregon forests, Biogeosciences, 10, 453-470, https://doi.org/10.5194/bg-10-453-2013, 2013.

Ise, T., Litton, C. M., Giardina, C. P., and Ito, A.: Comparison of modeling approaches for carbon partitioning: impact on estimates of global net primary production and equilibrium biomass of woody vegetation from MODIS GPP, J. Geophys. Res., 115, G04025, https://doi.org/10.1029/2010JG001326, 2010. 
Iversen, C. M., McCormack, M. L., Powell, A. S., Blackwood, C. B., Freschet, G. T., Kattge, J., Roumet, C., Stover, D. B., Soudzilovskaia, N. A., Valverde-Berrantes, O. J., van Bodegom, P. M., and Violle, C.: A global fine-root ecology database to address below-ground challenges in plant ecology, New Phytol., 215, 15-26, https://doi.org/10.1111/nph.14486, 2017.

Jenkins, J. C., Chojnacky, D. C., Heath, L. S., and Birdsey, R. A.: Comprehensive database of diameter-based biomass regressions for North American tree species, US Department of Agriculture, Forest Service, Newtown Square, PA, available at: https://www.fs.fed.us/ne/durham/4104/papers/ne_ gtr319_jenkins_and_others.pdf, 2004.

Kay, J. E., Deser, C., Phillips, A., Mai, A., Hannay, C., Strand, G., Arblaster, J. M., Bates, S. C., Danabasoglu, G., Edwards, J., Holland, M., Kushner, P., Lamarque, J.-F., Lawrence, D., Lindsay, K., Middleton, A., Munoz, E., Neale, R., Oleson, K., Polvani, L., and Vertenstein, M.: The Community Earth System Model (CESM) large ensemble project, A community resource for studying climate change in the presence of internal climate variability, B. Am. Meteor. Soc., 96, 1333-1349, 2015.

Keith, H., Mackey, B. G., and Lindenmayer, D. B.: Re-evaluation of forest biomass carbon stocks and lessons from the world's most carbon-dense forests, P. Natl. Acad. Sci., 106, 11635-11640, 2009.

Klesse, S., Etzold, S., and Frank, D.: Integrating tree-ring and inventory-based measurements of aboveground biomass growth: research opportunities and carbon cycle consequences from a large snow breakage event in the Swiss Alps, Eur. J. For. Res., 135, 297-311, 2016

Koven, C. D., Chambers, J. Q., Georgiou, K., Knox, R., NegronJuarez, R., Riley, W. J., Arora, V. K., Brovkin, V., Friedlingstein, P., and Jones, C. D.: Controls on terrestrial carbon feedbacks by productivity versus turnover in the CMIP5 Earth System Models, Biogeosciences, 12, 5211-5228, https://doi.org/10.5194/bg-125211-2015, 2015.

Lawrence, D. M., Oleson, K. W., Flanner, M. G., Thornton, P. E., Swenson, S. C., Lawrence, P. J., Zeng, X., Yang, Z.-L., Levis, S., Sakaguchi, K., Bonan, G. B., and Slater, A. G.: Parametrization improvements and functional and structural advances in version 4 of the Community Land Model, J. Adv. Model. Earth Syst., 3, M03001, https://doi.org/10.1029/2011MS000045, 2011.

Le Quéré, C., Raupach, M. R., Canadell, J. G., Marland, G., Bopp, L., Ciais, P., Conway, T. J., Doney, S. C., Feely, R. A., Foster, P., Friedlingstein, P., Gurney, K., Houghton, R. A., House, J. I., Huntingford, C., Levy, P. E., Lomas, M. R., Majkut, J., Metzl, N., Ometto, J. P., Peters, G. P., Prentice, I. C., Randerson, J. T., Running, S. W., Sarmiento, J. L., Schuster, U., Sitch, S., Takahashi, T., Viovy, N., van der Werf, G., and Woodward, F. I.: Trends in the sources and sinks of carbon dioxide, Nat. Geosci., 2, 831836, 2009

Le Quéré, C., Moriarty, R., Andrew, R. M., Canadell, J. G., Sitch, S., Korsbakken, J. I., Friedlingstein, P., Peters, G. P., Andres, R. J., Boden, T. A., Houghton, R. A., House, J. I., Keeling, R. F., Tans, P., Arneth, A., Bakker, D. C. E., Barbero, L., Bopp, L., Chang, J., Chevallier, F., Chini, L. P., Ciais, P., Fader, M., Feely, R. A., Gkritzalis, T., Harris, I., Hauck, J., Ilyina, T., Jain, A. K., Kato, E., Kitidis, V., Klein Goldewijk, K., Koven, C., Landschützer, P., Lauvset, S. K., Lefèvre, N., Lenton, A., Lima, I. D., Metzl, N., Millero, F., Munro, D. R., Murata, A., Nabel, J. E. M. S.,
Nakaoka, S., Nojiri, Y., O’Brien, K., Olsen, A., Ono, T., Pérez, F. F., Pfeil, B., Pierrot, D., Poulter, B., Rehder, G., Rödenbeck, C., Saito, S., Schuster, U., Schwinger, J., Séférian, R., Steinhoff, T., Stocker, B. D., Sutton, A. J., Takahashi, T., Tilbrook, B., van der Laan-Luijkx, I. T., van der Werf, G. R., van Heuven, S., Vandemark, D., Viovy, N., Wiltshire, A., Zaehle, S., and Zeng, N.: Global Carbon Budget 2015, Earth Syst. Sci. Data, 7, 349-396, https://doi.org/10.5194/essd-7-349-2015, 2015.

Li, H., Luo, L., Wood, E. F., and Schaake, J.: The role of initial conditions and forcing uncertainties in seasonal hydrologic forecasting, J. Geophys. Res., 114, D04114, https://doi.org/10.1029/2008JD010969, 2009.

Litton, C. M., Raich, J. W., and Ryan, M. G.: Carbon allocation in forest ecosystems, Glob. Change Biol., 13, 2089-2109, 2007.

Litvak, M. E.: AmeriFlux US-Vcm Valles Caldera Mixed Conifer, https://doi.org/10.17190/AMF/1246121, 2016.

Luyssaert, S., Inglima, I., Jung, M., Richardson, A. D., Reichstein, M., Papale, D., Piao, S. L., Schulze, E.-D., Wingate, L., Matteucci G., Aragao, L., Aubinet, M., Beer, C., Bernhofer, C., Black, K. G., Bonal, D., Bonnefond, J.-M., Chambers, J., Ciais, P., Cook, B., Davis, K. J., Dolman, A. J., Gielen B., Goulden, M., Grace, J., Granier, A., Grelle, A., Griffis, T., Grünwald, T., Guidolotti, G., Hanson, P. J., Harding, R., Hollinger, D. Y., Hutyra, L. R., Kolari, P., Kruijt, B., Kutsch, W., Lagergren, F., Laurila, T., Law, B. E., Le Maire, G., Lindroth, A., Loustau, D., Malhi, Y., Mateus, J., Migliavacca, M., Misson, L., Montagnani, L., Moncrieff, J., Moors, E., Munger, J. W., Nikinmaa, E., Ollinger, S. V., Pita, G., Rebmann, C., Roupsard, O., Saigusa, N., Sanz, M.-J., Seufert, G., Sierra, C., Smith, M.-L., Tang, J., Valentini, R., Vesala, T., and Janssens, I. A.: $\mathrm{CO}_{2}$ balance of boreal, temperate, and tropical forests derived from a global database, Glob. Change Biol., 13, 2509-2537, 2007.

Mahecha, M. D., Reichstein, M., Jung, M., Seneviratne, S. I., Zaehle, S., Beer, C., Braakhekke, M. C., Carvalhais, N., Lange, H., Le Maire, G., and Moors, E.: Comparing observations and process-based simulations of biosphere-atmosphere exchanges on multiple timescales, J. Geophys. Res., 115, G02003, https://doi.org/10.1029/2009JG001016, 2010.

Malhi, Y., Meir, P., and Brown, S.: Forests, carbon and global climate, Philos. T. Roy. Soc. A, 360, 1567-1591, 2002.

Malhi, Y., Doughty, C., and Galbraith, D.: The allocation of net primary productivity in tropical forests, Philos. T. Roy. Soc. B, 366, 3225-3245, 2011.

Mao, J., Thornton, P. E., Shi, X., Zhao, M., and Post, W. M.: Remote sensing evaluation of CLM4 GPP for the period 2000 to 2009 , J Climate, 25, 5327-5342, 2012.

Mao, J., Shi, X., Thornton, P. E., Hoffman, F. M., Zhu, Z., Ranga, B., and Myneni, R. B.: Global latitudinal-asymmetric vegetation growth trends and their driving mechanisms: 1982-2009, Remote Sens., 5, 1484-1497, 2013.

Masek, J. G., Huang, C., Wolfe, R., Cohen, W., Hall, F., Kutler, J., and Nelson, P.: North American forest disturbance mapped from a decadal Landsat record, Remote Sens. Environ., 112, 2914 2926, 2008.

Megonigal, J. P., Conner, W. H., Kroegger, S., and Sharitz, R. R.: Aboveground production in southeastern floodplain forests: a test of the subsidy-stress hyphothesis, Ecology, 78, 370-384, 1997.

Munger, J. W.: AmeriFlux US-Ha1 Harvard Forest EMS Tower (HFR1), https://doi.org/10.17190/AMF/1246059, 2016. 
Nadelhoffer, K. J. and Raich, J. W.: Fine root production estimates and belowground carbon allocation in forest ecosystems, Ecology, 73, 1139-1147, 1992.

Negron-Juarez, R., Koven, C.D., Riley, W. J., Knox, R. G., and Chambers, J. Q.: Observed allocations of productivity and biomass, and turnover times in tropical forests are not accurately represented in CMIP5 Earth system models, Environ. Res. Lett., 10, 064017, https://doi.org/10.1088/17489326/10/6/064017, 2015.

Newman, G. S., Arthur, M. A., and Muller, R. N.: Above- and belowground net primary production in a temperate mixed deciduous forest, Ecosystems, 9, 317-329, 2006.

Novick, K. A. and Phillips, R.: AmeriFlux US-MMS Morgan Monroe State Forest, https://doi.org/10.17190/AMF/1246080, 2016.

Oishi, C., Novick, K. A., and Stoy, P.: AmeriFlux US-Dk2 Duke Forest-hardwoods, https://doi.org/10.17190/AMF/1246047, 2016.

Oleson, K., Lawrence, D. M., Bonan, G. B., Drewniak, B., Huang, M., Koven, C. D., Levis, S., Li, F., Riley, W. J., Subin, Z. M., Swenson, S. C., Thornton, P. E., Bozbiyik, A., Fisher, R., Heald, C. L., Kluzek, E., Lamarque, J.-F., Lawrence, P. J., Leung, L. R., Lipscomb, W., Muszala, S., Ricciuto, D. M., Sacks, W., Sun, Y., Tang, J., and Yang, Z.-L.: Technical Description of version 4.5 of the Community Land Model (CLM), NCAR Technical Note NCAR/TN-503+STR, Boulder, Colorado, 420 pp., 2013.

Pan, Y., Birdsey, R. A., Fang, J., Houghton, R., Kauppi, P. E., Kurz, W. A., Phillips, O. L., Shvidenko, A., Lewis, S. L., Canadell, J. G., Ciais, P., Jackson, R. B., Pacala, S. W., McGuire, A. D., Piao, S., Rautiainen, A., and Hayes, D.: A large and persistent carbon sink in the world's forests, Science, 333, 988-993, 2011.

Phillips, R. P., Ibáñez, I., D’Orangeville, L., Hanson, P. J., Ryan, M. G., and McDowell, N. G.: A belowground prespective on the drought sensitivity of forests: towards improved understanding and simulation, Forest Ecol. Manag., 380, 309-320, 2016.

Piao, S. L., Ito, A., Li, S. G., Huang, Y., Ciais, P., Wang, X. H., Peng, S. S., Nan, H. J., Zhao, C., Ahlström, A., Andres, R. J., Chevallier, F., Fang, J. Y., Hartmann, J., Huntingford, C., Jeong, S., Levis, S., Levy, P. E., Li, J. S., Lomas, M. R., Mao, J. F., Mayorga, E., Mohammat, A., Muraoka, H., Peng, C. H., Peylin, P., Poulter, B., Shen, Z. H., Shi, X., Sitch, S., Tao, S., Tian, H. Q., Wu, X. P., Xu, M., Yu, G. R., Viovy, N., Zaehle, S., Zeng, N., and Zhu, B.: The carbon budget of terrestrial ecosystems in East Asia over the last two decades, Biogeosciences, 9, 3571-3586, https://doi.org/10.5194/bg-9-3571-2012, 2012.

Randerson, J. T., Hoffman, F., Thornton, P. E., Mahowald, N. M., Lindsay, K., Lee, Y.-H., Nevison, C. D., Doney, S. C., Bonan, G., Stöckli, R., Covey, C., Running, S. W., and Fung, I. Y.: Systematic assessment of terrestrial biogeochemistry in coupled climate-carbon models, Glob. Change Biol., 15, 2462-2484, 2009.

Reichstein, M., Falge, E., Baldocchi, D., Papale, D., Aubinet, M., Berbigier, P., Bernhofer, C., Buchmann, N., Gilmanov, T., Granier, A., Grünwald, T., Havránková, K., Ilvesniemi, H., Janous, D., Knohl, A., Laurila, T., Lohila, A., Loustau, D., Matteucci, G., Meyers, T., Miglietta, F., Ourcival, J.-F., Pumpanen, J., Rambal, S., Rotenberg, E., Sanz, M., Tenhunen, J., Seufert, G., Vaccari, F., Vesala, T., Yakir, D., and Valentini, R.: On the separation of net ecosystem exchange into assimilation and ecosystem respiration: review and improved algorithm, Glob. Change Biol., 11, 1424-1439, 2005.

Richardson, A. D., Williams, M., Hollinger, D. Y., Moore, D. J. P., Dail, D. B., Davidson, E. A., Scott, N. A., Evans, R. S., Hughes, H., Lee, J. T., Rodrigues, C., and Savage, K.: Estimating parameters of a forest ecosystem $\mathrm{C}$ model with measurements of stocks and fluxes as joint constraints, Oecologia, 164, 25-40, 2010.

Rodell, M., Houser, P. R., Berg, A. A., and Famiglietti, J. S.: Evaluation of 10 methods for initializing a land surface model, J. Hydrometeorol., 6, 146-155, 2005.

Runkle, J. R.: Changes in Southern Appalachian canopy tree gaps sampled thrice, Ecology, 79, 1768-1780, 1998.

Schulze, E.-D., Wirth, C., and Heimann, M.: Managing forests after Kyoto, Science, 289, 2058-2059, 2000.

Sevanto, S. and Dickman, L. T.: Where does the carbon go? - Plant carbon allocation under climate change, Tree Physiol., 35, 581$584,2015$.

Shi, M., Fisher, J. B., Brzostek, E. R., and Phillips, R. P: Carbon cost of plant nitrogen acquisition: global carbon cycle impact from an improved plant nitrogen cycle in the Community Land Model, Glob. Change Biol., 22, 1299-1314, 2016.

Shi, X., Mao, J., Thornton, P. E., and Huang, M.: Spatiotemporal patterns of evapotranspiration in response to multiple environmental factors simulated by the Community Land Model, Environ. Res. Lett., 8, 024012, https://doi.org/10.1088/17489326/8/2/024012, 2013.

Sierra, C. A., Müller, M., Metzler, H., Manzoni, S., and Trumbore, S. E.: The muddle of ages, turnover, transit, and residence times in the carbon cycle, Glob. Change Biol., 23, 1763-1773, 2017.

Song, X., Zeng, X.-D., and Li, F.: Evaluation of the individual allocation scheme and its impacts in a dynamic global vegetation model, Atmos. Ocean. Sci. Lett., 9, 38-44, 2016.

Stearns, F. W.: Ninety years change in a northern hardwood forest in Wisconsin, Ecology, 30, 350-358, 1949.

Stokes, M. A. and Smiley, T. L.: An introduction to tree-ring dating. University of Chicago Press, Chicago, Illinois, USA, 1968.

Stoy, P., Oishi, C., and Novick., K. A.: AmeriFlux US-Dk3 Dule Forest - loblolly pine, https://doi.org/10.17190/AMF/1246048, 2016.

Thornton, P. E. and Zimmerman, N. E.: An improved canopy integration scheme for a Land Surface Model with prognostic canopy structure, J. Climate, 20, 3902-3923, 2007.

Thum, T., MacBean, N., Peylin, P., Bacour, C., Santaren, D., Longdoz, B., Loustau, D., and Ciais, P.: The potential benefit of using forest biomass data in addition to carbon and water flux measurements to constrain ecosystem model parameters: case studies at two temperate forest sites, Agr. Forest Meteorol., 234, 48-65, 2017.

Thurner, M., Beer, C., Ciais, P., Friend, A. D., Ito, A., Kleidon, A., Lomas, M. R., Quegan, S., Rademacher, T. T., Schaphoff, S., Tum, M., Wiltshire, A., and Carvalhais, N.: Evaluation of climate-related carbon turnover processes in global vegetation models for boreal and temperate forests, Glob. Change Biol., 23, 3076-3091, https://doi.org/10.1111/gcb.13660, 2017.

Tilman, D.: Plant strategies and the dynamics and structure of plant communities. Monographs in Population Biology 26, Princeton University Press, Princeton, New Jersey, USA, 1988.

van Mantgem, P., Stephenson, N. L., Byrne, J. C., Daniels, L. D., Franklin, J. F., Fulé, P. Z., Harmon, M. E., Larson, A. J., Smith, 
J. M., Taylor, A. H., and Veblen, T. T.: Widespread increase of tree mortality rates in the western United States, Science, 323, 521-524, 2009.

Waring, R. H., Landsberg, J. J., and Williams, M.: Net primary production of forests: a constant fraction of gross primary production?, Tree Physiol., 18, 129-134, 1998.

Warren, J. M., Hanson, P. J., Iversen, C. M., Kumar, J., Walker, A. P., and Wullschleger, S. D.: Root structural and functional dynamics in terrestrial biosphere models - evaluation and recommendations, New Phytol., 205, 59-78, 2015.

Weng, E., Farrior, C. E., Dybzinski, R., and Pacala, S. W.: Predicting vegetation type through physiological and environmental interactions with leaf traits: evergreen and deciduous forests in an earth system modeling framework, Glob. Change Biol., 23, 2482-2498, https://doi.org/10.1111/gcb.13542, 2016.

Wolf, A., Field, C. B., and Berry, J. A.: Allometric growth and allocation in forests: a perspective from FLUXNET, Ecol. Appl., 21, 1546-1556, 2011.

Wood, J. D. and Gu, L.: AmeriFlux US-MOz Missouri Ozark site, https://doi.org/10.17190/AMF/1246081, 2016.
Xia, J., Chen, Y., Liang, S., Liu, D., and Yuan, W. Global simulations of carbon allocation coefficients for deciduous vegetation types, Tellus B, 67, 28016, https://doi.org/10.3402/tellusb.v67.28016, 2015.

Xia, J. Y., Luo, Y. Q., Wang, Y.-P., Weng, E. S., and Hararuk, O.: A semi-analytical solution to accelerate spin-up of a coupled carbon and nitrogen land model to steady state, Geosci. Model Dev., 5, 1259-1271, https://doi.org/10.5194/gmd-5-1259-2012, 2012.

Yang, Z.-L., Dickinson, R. E., Henderson-Sellers, A., and Pitman, A. J.: Preliminary study of spin-up processes in land surface models with the first stage data of Project for Intercomparison of Land Surface Parameterization Schemes Phase 1(a), J. Geophys. Res., 100, 16553-16578, 1995.

Zaehle, S. and Friend, A. D.: Carbon and nitrogen cycle dynamics in the O-CN land surface model: 1. Model description, site-scale evaluation, and sensitivity to parameter estimates, Global Biogeochem. Cy., 24, GB1005, https://doi.org/10.1029/2009GB003521, 2010. 